\title{
CERÁMICAS ISLÁMICAS DEL CASTILLO DE GIBRALEÓN (Huelva)
}

\author{
Juan Aurelio Pérez Macías
}

Universidad de Huelva

Recibido: 13/01/2014

Revisado: 24/02/2014
Aceptado: $10 / 03 / 2014$

Publicado: 20/05/2014

\section{RESUMEN}

Se estudian en este trabajo las cerámicas de cronología islámica exhumadas en las excavaciones del Castillo de Gibraleón (Huelva), que remiten en su mayor parte a una cronología de la segunda mitad del siglo XII y primera mitad del siglo XIII. Estas cerámicas se encuentran asociadas a estructuras que debían formar parte de la alcazaba de la ciudad, convertida en época bajo medieval en alcázar señorial. Aunque no se encuentran elementos constructivos de la muralla que rodeó a la ciudad en época islámica, se propone el plano de la misma a partir del estudio de la actual trama urbanística.

Palabras Clave

Cerámica; Islámica; Suroeste peninsular; Madina; Alcazaba.
ABSTRAC

In this work we study the islamic pottery from the excavations of the Castle of Gibraleón (Huelva, SW Spain), which refer mostly to a chronology of the second half of the twelfth century and the first half of the thirteenth century. The pottery is associated with structures that should be part of the citadel of the city, converted during the later medieval times in lord's castle. Are not constructive elements of the wall that surrounded the city in the Islamic period, but the plane is proposed based on the study of current urban design.

\section{KEYWORDS}

Pottery; Southwest Spain; Madina; Alcazaba.

japerez@dhis1.uhu.es 


\section{Para Juana Bedia García, Dulcis vivas.}

Después de la pesadumbre en la que nos embargó la muerte de Juana Bedia, quiero dedicarle este trabajo sobre las cerámicas islámicas de Gibraleón. Proceden de una de sus primeras excavaciones, y no encuentro mejor manera de reavivar su memoria que recordarla con las páginas que siguen a continuación.

Según un fragmento de ánfora de tipo fenicio aparecida en esas excavaciones (Serrano, Campos y Pérez, e.p.), el origen de Gibraleón parece remontarse al menos al siglo VI a.C., pero la falta de otros elementos muebles prerromanos invita a considerar que fue una ocupación efímera que se abandonó con la crisis del mundo tartésico a fines del siglo VI a.C. No se volvería a ocupar hasta época alto-medieval, cuando las fuentes documentales árabes recogen su topónimo como ciudad.

Sobre estas cuestiones históricas de Gibraleón destaca uno de los trabajos que D. Félix Hernández Giménez dedicó a la caminería histórica hispana (Hernández Giménez, 1958), el que estudia el posible vado del Odiel por un camino de origen romano $(A b$ ostio fluminis Anae Emeritam usque..). Planteó que lo más lógico era que la calzada romana, que partía de la desembocadura del Guadiana y pasaba por Huelva, Niebla y Tejada la Nueva en dirección a Itálica, siguiera un recorrido paralelo a la costa, y el punto más cercano a Huelva con mejores condiciones para atravesar el Odiel era a la altura de Gibraleón, donde terminan las marismas, que complicaban su vado (figura 1). El vado lo sitúa en un badén, llamado Zua o Azuda por salir de él un muro de contención que retiene aguas para alimentar un molino harinero aguas abajo. Este badén tiene unos $4 \mathrm{~m}$ de ancho en el tablero, y reconoció en su trayectoria quebrada dos obras distintas. La más antigua un muro con algunos vanos de desagüe de unos $0,70 \mathrm{~m}$ de luz y una calzada de 3,50 m de ancho, pavimentada por piezas de pizarra irregulares con longitudes que oscilan entre los 0,60 y 0,70 m. En esta obra se realiza en un segundo momento una reparación del pavimento con piedras finas de río colocadas de canto, que se refuerza con andenes de ladrillos con módulo de 28/14/4,5 cm y bovedillas semicirculares de ladrillo de igual módulo con la función de aliviaderos. La primera fase de la obra fue datada en época romana a partir de la noticia de al-Rāzī sobre la existencia de puentes antiguos en el Odiel.
B. Pavón Maldonado (1990) subraya que Gibraleón aparece recogido en las fuentes árabes desde época de al-Razī en relación con el río Odiel, del que nos comenta que es llamado río de los puentes debido a que en este río quedaban muchos fundamentos de antiguos puentes, en el mismo sentido que antes había planteado F. Hernández. Pavón Maldonado se cuestiona si el nombre de al-Qanatir con el que fue conocido el río Odiel hacía referencia a verdaderos puentes o a pontones y badenes, cuyos cimientos se conservan todavía hoy día. Pavón Maldonado considera que el módulo de los ladrillos de la segunda fase del badén propuesta por $\mathrm{F}$. Hernández puede datarlo en los siglos XI y XII. No obstante, esos ladrillos de módulo medieval se encuentran en conexión estratigráfica tanto con el pavimento de grandes lastras, supuestamente romano, como con el de piedras menudas, que se asigna a su reparación medieval, y no existen recursos hidráulicos, ni técnicas constructivas de factura netamente romanas. Esta modalidad de badenes, sin estribos y tajamares ni arquillos aliviaderos sobre ellos son desconocidos en época romana.

La investigación actual ha descartado ese trazado litoral de la calzada (Bendala Galán, 1987). Se propone un trayecto desde el Guadiana hasta Tharsis, en cuyas proximidades se encontraría la mansio de ad Rubrae, y desde aquí a Huelva, con lo que el paso del Odiel podía realizarse igualmente aguas arriba, en algunas de las innumerables pasadas que jalonan su curso después de la bifurcación de la Rivera de Meca (Pasada de la Aceña, Pasada del Castillito, etc.). Si el paso del Odiel en este punto hubiera sido importante en época romana, es posible que estuviera acompañado por algún asentamiento romano, como sucede en el caso de Niebla. Sin embargo, en época romana se optó por un modelo de asentamiento de campiña, como Santa Ana o Camino Coronillas (Bedia, Teba y Pérez, 1985), y no tenemos constancia de que se revitalizará el despoblado tartésico. El río era en estos momentos una magnífica vía de comunicación, a través de la cual era posible enlazar los asentamientos de economía mixta que se encuentran a ambos lados de su estuario, algunos con verdadera vocación portuaria con las tierras del interior, como el de Casa de las Monjas, apenas un kilómetro aguas abajo de Gibraleón. Lo coherente es pensar que el badén esté relacionado con la consolidación del asentamiento de Gibraleón en época medieval, pues no hay que olvidar que el trayecto que sigue el badén se dirige 
precisamente a la zona del Castillo de Gibraleón, el barrio más primitivo de la villa, donde se encuentran los restos islámicos que vamos a presentar en este trabajo.

Gibraleón debió surgir pues por la necesidad de vadear el Odiel en el punto más cercano a la ensenada que forman las marismas del Odiel, y en relación a un nuevo camino de recorrido costero hacia Ayamonte, jalonado de fundaciones islámicas, caso de Cartaya, Lepe, y Ayamonte, que acabará convertido en Camino Real a Sevilla desde comienzos de la Edad Moderna. El trazado de este Camino Real seguía por Ayamonte, Pozo del Camino, La Redondela, Lepe, Cartaya, Venta de la Mezquita, y Gibraleón, tal como se desprende de las indicaciones de la Descripción o Cosmografía de España de Fernando Colón, que nos aclara además que el Odiel se pasaba por vado y por barca (Hernández Giménez, 1958, 138). Gibraleón fue además un importante nudo de comunicaciones, pues desde este punto se bifurcaba otro camino hacia Mertola, conocido en época bajo medieval como "Carrera de Mértola” (Pérez Macías,
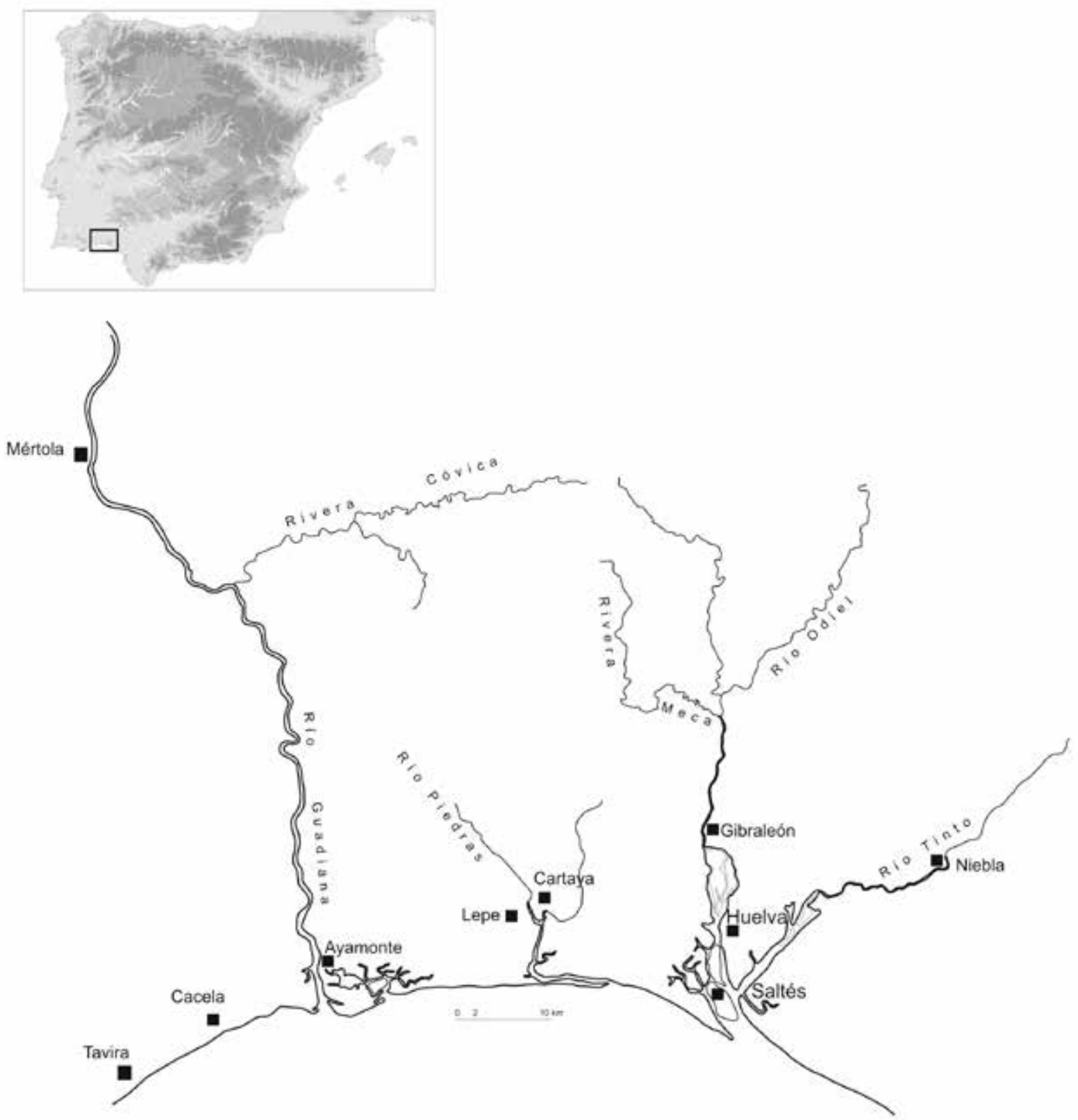

Figura 1. Situación de Gibraleón y asentamientos de su entorno geográfico. 
2012). Estos dos caminos facilitaban el tránsito al occidente de al-Andalus, hacia los distritos actuales de Algarbe y Baixo Alentejo.

Las citas a Gibraleón se hacen corrientes pues a partir de época islámica, y su nombre, Ŷabal al'Uyūn, se ha traducido como Monte de las Fuentes (Asín Palacios, 1944, 107). Conviene señalar que el castillo de Gibraleón se sitúa en un cerro próximo al río Odiel, en el que los textos medievales recogen la existencia de una fuente denominada La Fontanilla, que se encontraba junto a la puerta del castillo, en la actual Calle de la Fuente.

La primera referencia se remonta al siglo $\mathrm{X}$, en la obra de al-Rāzī, quien la registra como una de las ciudades dependientes de Niebla y remarca su situación junto al Wadi al-Qanatir (Odiel), llamado así porque en sus orillas quedaban vestigios de puentes (Pavón Maldonado, 1990 y 1996).

Según al-'Udrī (s. XI) Gibraleón era una de las cabeceras del distrito de Niebla. Sus límites se extenderían según Roldán Castro (1993) hasta los distritos de Huelva y al-Madina (Niebla), y así parece deducirse de la posterior división de términos que se realiza después de la conquista cristiana (1267) con "moros sabidores de los términos" (Anasagasti y Rodríguez, 1984, 20). Al norte lindaría con las tierras de Aroche, pertenecientes al distrito de Beja (Portugal).

Ya en el siglo XII al-Idrīsī divide al-Andalus en aqālīm, y sitúa en el iqlim del Aljarafe a las ciudades de Aznalcázar, Niebla, Huelva, Saltés y Gibraleón (Mazzoli-Guintard, 2000, 256), pero durante la conquista cristiana la tierra Niebla no forma parte del Aljarafe, cuyas principales cabeceras eran San Juan de Aznalfarache, Aznalcázar, Sanlúcar la Mayor, y Tejada la Nueva (González, 1951).

Según al-Idrīsī Gibraleón entraría en la categoría de madīna máqil, en la que también se encontraban las ciudades de Niebla y Saltés, mientras que a Huelva la describe como madīna máqil-hiṣn. Mazzoli-Guintard (2000) opina que tras estas denominaciones a veces es verdaderamente imposible obtener una idea de la verdadera categoría de la ciudad, pero en general puede considerarse que se trata de ciudades de segundo orden. Niebla sería la ciudad más importante de la zona a tenor de su extensión (Mazzoli-Guintard, 2000), y de ahí que en la mayor parte de los autores aparezca como cabecera de su Cora. En el modelo de Huelva es evidente que la existencia de un núcleo fortificado en torno al Cabezo de San Pedro pudo dar origen a esa comparación como ciudad-castillo (madīna hiṣn), pero no es tan claro en Niebla y Gibraleón, ciudades amuralladas, pero ubicadas en terrenos más llanos de campiña. Además, en estos últimos ejemplos se da una circunstancia común, se encuentran sobre un río, en un importante lugar de comunicación, Niebla sobre el río Tinto, cuyo puente de origen romano (i?) permitía el vado, Gibraleón sobre el río Odiel, donde el badén de origen medieval era una garantía para la caminería con el área occidental de la cora, donde se encontraban otros lugares importantes sobre el vado de los ríos, como Lepe en el río Piedras (Valencia Rodríguez, 1996), y Ayamonte en el río Guadiana, la llave que abría la puerta al extremo de Garb al-Andalus. Aunque al-Idrīsī no tuviera pretensiones de sistematizar la clasificación de las ciudades, parece razonable pensar que con esas clasificaciones estaría indicando los rasgos más destacados de los asentamientos.

Ibn Galid (s. XII) cita a Gibraleón dentro de las ciudades de la demarcación de Niebla, junto con Qirqiya, que Roldán Castro (1993) identifica con Cartaya.

Otras descripciones parecidas son las de Yāqūt al-Hamawī (ss. XII-XIII), que la nombra como al-'Uyūn y añade que también se la conoce como Ŷabal al-'Uyūn (Roldán Castro, 1993).

Al-Himyarī (ss. XIII-XIV) la sitúa en al-Andalus al-Garbi y hace depender a Huelva (Awnaba) del distrito de Gibraleón (Roldán Castro, 1993).

Gibraleón participó también en algunos de los episodios de la fitna contra el poder central de Córdoba, lo que apunta que desde época emiral era un núcleo de cierta importancia. En el año 889-890 se rebelaron Ibn Jașīb en Monte Mayor y b. 'Ufayr en Gibraleón. El movimiento de resistencia en el suroeste alcanzó tal virulencia que al final se produjo la lucha de los distintos señores para hacerse con el poder, en la que jugaron las alianzas de unos señores con otros, principalmente los de Faro, Beja y Badajoz. Es en este juego de alianzas en el que aparece la figura de b. 'Ufayr de Gibraleón, que llegó a la alianza con b. Bark de Faro y b. Malik de Beja después de haber conseguido el liderazgo de los muladíes de Niebla. Estos tres señores se enfrentaron a Ibn Ŷillīqī de Badajoz y su aliado b. Maslama de Aroche, que robaron ganado en las tierras señoreadas por b. 'Ufayr y hostigaron la fortaleza de al-Munt (Almonte). La paz no llegaría hasta el 896, tras el nombramiento de un nuevo gobernador militar en Niebla, al-Abbādī, al que rindieron obe- 
diencia los jefes muladíes y recibieron el amān, con lo que se regularizó el cobro de impuestos (Roldán Castro, 1993; García Sanjuán, 2003; Pérez Macías, 2006).

Dentro de la clasificación de las ciudades andalusíes que plantea C. Mazzoli-Guintard (2000), habría que situar a Gibraleón en la categoría de ciudadpuente, aquéllas que se encontraban en un punto de vado de un río en una importante vía de comunicación, un tipo de ciudad que tiene sus precedentes en época prerromana, como sucede en Niebla, y romana, con un ejemplo clásico en Mérida. Es un carácter que se afianza en ellas con la construcción de un puente que facilitara el paso en todo tiempo. En Niebla y Gibraleón estos puentes, de distinta envergadura en cada caso, fueron obras que contribuyeron a incrementar la posición estratégica de estas ciudades. Para otra ciudad islámica de Huelva, Saltés, hay que resaltar que se convirtió en un lugar que daba acceso a Huelva desde la ría de Punta Umbría (Bazzana y Bedia, 2005), una salida menos peligrosa que el canal del Padre Santo, cuyos bajos eran una amenaza constante a la navegación; desde Saltés era posible incluso una navegación de cabotaje a lo largo de la costa atlántica, pues el camino terrestre por el vado de Gibraleón se complicaba por los terrenos marismeños de los ríos Piedras, Carreras, y Guadiana, donde en algunos puntos era indispensable el uso de barcas, como la Barca del río Piedras en Lepe.

Un índice del rango de Gibraleón es el número de veces que se nombra su topónimo en las fuentes árabes. Según F. Roldán es uno de los topónimos onubenses que mayor número de veces aparece en las fuentes árabes (Roldán Castro, 1993, 116). Mazzoli-Guintard $(2000,448)$ recoge seis citas frente a las 23 de Niebla y a las 5 de Huelva, y aunque García Sanjuán $(2003,139)$ discute este dato numérico, refleja muy bien la posición de estas tres ciudades en el esquema administrativo de la zona. Estos datos dan sentido a la clasificación de Niebla como ciudad central de la cora y Huelva y Gibraleón como ciudades de menor entidad, pero cabeceras de sus más importantes distritos junto con el de la propia amelía de Niebla. Estas tres ciudades serían tres distritos de la tierra de campiña, la comarca de mayor proyección económica del amplio alfoz de Niebla. Su importancia económica se refleja en las ocultaciones de tesorillos en el inicio de la conquista almohade del suroeste de al-Andalus (Mateu y Llopis, 1952; Rodríguez Martinho, 1972).
Las únicas noticias sobre el Castillo de Gibraleón después de la conquista cristiana se refieren a los problemas derivados de su tenencia en los cambios de jurisdicción señorial en Gibraleón. No conocemos su fecha exacta de conquista, pero lo más probable es que pasara a manos cristianas después de la conquista de Niebla en 1262. Quizás antes sufriera algún tipo de acoso o entrada por parte de las tropas portuguesas de la Orden de Santiago, que habían pasado el Guadiana después de la conquista de Mértola, tomando Alfayat de la Penha y Ayamonte, y que estableció como límite de su territorio el río Odiel, cuyo nombre aparece en la forma de evolución en portugués del término árabe wadi (Odiana, Odivelas, Odeleite, Odemira, etc.), diferente a como lo hace en castellano (Guadiana, Guadalquivir, etc.). Éste es el sentido en el que se expresa un documento portugués del Sancho II después de la conquista de Ayamonte, en el que establece la frontera en el río Odiel: "contra Geuoleon, et contra Olva et contra Saliez dividantur termini predicti Castelli per Odael.." (Amador de los Ríos, 1891, 772). Según las fuentes árabes Gibraleón, Saltés y otras plazas fueron entregadas a Alfonso X el Sabio por Ibn Mahfūz en 1249, como garantía de paz para Niebla (Roldán Castro, 2005, 383; Ramírez del Río, 2012, 18).

Después de su conquista Gibraleón fue villa de realengo, y en 1282 Alfonso X confirmó sus fueros $\mathrm{y}$ franquezas. Las primeras noticias sobre las murallas de Gibraleón proceden de este momento, pues en 1267 Alfonso X cede el montazgo que se cobrase en estos términos para la construcción y reparación de la muralla y sus torres (Ladero Quesada, 1977, 36), lo que hace suponer que su estado de conservación no era el adecuado. En este mismo momento se lleva a cabo la delimitación de su término, en 1267 con los de Huelva, Niebla y Saltés, y en 1268 con los de Huelva y Ayamonte (Ladero Quesada, 1977, 36).

Un primer cambio de régimen se produjo cuando, debido al Conflicto del Algarve, Alfonso X cedió toda la tierra de Niebla como señorío vitalicio a su hija bastarda Doña Beatriz, casada con Alfonso III de Portugal.

Posteriormente volvería a la corona, pero finalmente sería convertida definitivamente en tierra de señorío por su donación a Alfonso de la Cerda en la minoría del rey Fernando IV. Esta donación era una compensación por su renuncia a la corona para la resolución definitiva del problema sucesorio del reino 
castellano tras la muerte de Fernando de la Cerda, hijo mayor de Alfonso X (Ladero Quesada, 1977).

$\mathrm{Al}$ poco de concederse la villa de Gibraleón a Alfonso de la Cerda, éste confirma en 1315 los privilegios que tenía cuando estuvo en poder de la corona, así como varias mercedes, el derecho de los vecinos que tenían casa a labrar, a moler trigo en las aceñas y molinos, etc. (Pardo Rodríguez, 1980, doc. 6). En este documento se distingue entre la villa y el arrabal que se había formado extramuros, pues se exime al concejo de Gibraleón "la postura de los cuatro mil maravedíes e de los omes e de las mujeres que nos avian de dar para la lavor de muro según pusieron conuxco los sus mandaderos...". Es evidente que desde este momento se comienzan a realizar reformas en las murallas, dejando una parte para morada de los representantes de la casa de la Cerda. De ahí que en adelante se mencione simultáneamente al castillo como al alcázar. Es muy probable que el alcázar o castillo corresponda a la alcazaba y el muro a la cerca que rodeaba la ciudad. Al mecenazgo de Alfonso de la Cerca se debe también la construcción extramuros del Convento de Nuestra Señora del Carmen en 1331, donde sería finalmente sepultado en 1335 tras su muerte en la defensa de Gibraltar (Ladero Quesada, 1977, 41).

En 1347 muere su hijo Juan Alonso de la Cerda y hereda Gibraleón su hermano Luís de la Cerda, con la condición testamentaria de que abonase una cantidad antes de un año y si al cabo del cual no se satisfacía se pondrían en venta las villas de Huelva y Gibraleón. No se pagó la cantidad y tras su compra volvió de nuevo a manos de la corona.

En tiempos de Pedro I se otorga en señorío a su hermano el infante D. Fernando (1361), pero tras la victoria de Enrique se cede a Alfonso Pérez de Guzmán (1366).

Más tarde reclaman Gibraleón en un largo pleito los condes de Medinaceli, en virtud de los derechos que tenía Isabel de la Cerda, última heredera con derechos, casada con Beltrán Bearne, conde de Medinaceli y reconocido trastamarista (Pardo Rodríguez, 1980). En 1379 se reconocen estos derechos a los condes de Medinaceli y en 1380 se compensa a Alvar Pérez de Guzmán con otros bienes raíces, entre ellos la aldea de Villalba del Alcor y la aldea y castillo de Palos, pero estas propiedades no debieron satisfacerlo, pues el 1390 volvió a reclamar el señorío de Gibraleón.

Es en el contexto de los distintos enfrentamientos de Alvar Pérez de Guzmán y Beltrán de
Bearne en el que encontramos algunas referencias al castillo de Gibraleón. Entre esos documentos destacan los que atañen a la tenencia del castillo, como el que comenta el incidente de la toma de posesión del castillo por Beltrán de Bearne, al que se opuso de manera violenta su alcayde Lope Fernández (Pardo Rodríguez, 1980, doc. 43). En este documento de 1379 se cita el castillo como alcázar, formado por torres y lienzos del adarve, torre mayor, y una barrera, que interpretamos como una pequeña barbacana: ".. e otrosi estando e paresçiendo en las torres del dicho alcaçar en el lienço del adarve entre las dichas torres e en la barrera del dicho alcaçar...E luego a poca ora paresçio un ome armado de armas ençima de la torre mayor del dicho alcaçar, que dezian que llamaban torre del homenaje..". En el transcurso del enfrentamiento, el alcázar de Gibraleón fue entregado a Micer Lanzarote, almirante de Portugal, hasta que el rey decidiera en el pleito, un documento en el que se cita el postigo del alcázar: “...en este dicho dia ante las puertas del postigo del alcaçar...” (Pardo Rodríguez, 1980, doc. 45), hasta que el almirante de Portugal toma posesión del castillo en nombre de los condes de Medinaceli en Diciembre de 1379 (Pardo Rodríguez, 1980, doc. 47). Sin embargo, en Enero Juan I pide que no se realice la entrega definitiva hasta que se aclare el asunto (Pardo Rodríguez, 1980, doc. 48), y lo cede a Juan Ruiz en tanto se solventa el pleito (Pardo Rodríguez, 1980, doc. 49). No es hasta Septiembre de 1380 cuando finalmente reconoce como señores de Huelva y Gibraleón a los condes de Medinaceli (Pardo Rodríguez, 1980, doc. 51). En otro documento de esta serie se describen también otros elementos cercanos al castillo, como la fuente llamada de la Fontanilla: “..en este dicho día a ora de misas estando ante la puerta del alcaçar et castillo de la villa, contra la fuente, que dizen la fontanilla (Pardo Rodríguez, 1980, doc. 65). La Torre Mayor sería una de las partes más destacadas del alcázar, pues se subraya su importancia en los pleitos de homenaje que realizan los alcaydes a los representantes del conde de Medinaceli:”..dieron e entregaron al dicho Gonçalo Sanchez Moço en nombre de los dichos sennores conde e condesa el dicho castillo e alcaçar e la torre del homenaje de ello, et los canados e las llaves de ello.." (Pardo Rodríguez, 1980, doc. 66).

Finalmente, poco antes de morir Juan I ordenó que Isabel de la Cerda devolviera Gibraleón a Alvar Pérez de Guzmán (Ladero Quesada, 1977, 47). 
El matrimonio de Isabel de Guzmán, hija de Alvar Pérez de Guzmán, con Pedro López de Stuñiga, vendría a significar un nuevo giro en estos enfrentamientos. En 1400 Enrique III ordenaba que se cumpliese la sentencia sobre la devolución de Gibraleón a los herederos de Alvar Pérez de Guzmán, y finalmente en 1407 Isabel de Guzmán recibió pleito-homenaje del alcaide del castillo de Gibraleón (Ladero Quesada, 1977, 59). Gibraleón pasó de este modo a la casa de los Stuñiga.

El señorío de Gibraleón se convierte en marquesado en la persona de Alfonso II de Zuñiga y Pérez de Guzmán, Segundo Duque de Béjar, por concesión del emperador Carlos V, y al morir sin herederos le sucede su sobrina Teresa de Zuñiga y Guzmán, marquesa de Ayamonte, que une los dos marquesados de la zona occidental de la costa de Huelva. En 1568 su nieto Francisco III Diego de Zuñiga y Sotomayor se instaló en Gibraleón, reformó el castillo para transformarlo en Casa Palacio de los Duques de Béjar y Marqueses de Gibraleón, y financió obras piadosas, como el Convento de la Madre de Dios del Vado (Mira Toscano, 2012).

A pesar de todas estas vicisitudes por la que ha pasado a lo largo de épocas bajo-medieval y moderna, nuestro conocimiento de la planta del Castillo de Gibraleón se reduce al mapa que acompaña un Proyecto de Reconstrucción del Castillo a fines del siglo XVII (1667), realizado por el ingeniero militar D. Luís de Coen y Campos, pero en esa fecha la fortaleza debería estar muy abandonada y ruinosa. En el plano de Luis Coen y Campos se dibuja la planta del Palacio, pero su fisonomía debería estar ya muy desfigurada. Se reconoce una zona próxima a la puerta donde todavía se conservaban algunas torres, $y$ un gran espacio cercado sin ninguna construcción, que en la leyenda del plano aparece descrito como jardín. Su capacidad de defensa debería estar ya tan mermada que en el proyecto se propone la construcción de un baluarte estrellado con terraza sobre la puerta y dos baluartes junto a esta entrada (Duclos Bautista, 2002). El jardín correspondería a la parte del castillo que no era el alcázar, y es posible que la planta del Palacio corresponda al antiguo alcázar, reformado por los Duques de Béjar. Sabemos que ya en el siglo XVIII (1753) se había descartado su uso militar, y debido al mal estado de las dependencias del castillo el Concejo de Gibraleón aprueba que se alquile una casa para alojar a la plana mayor del Regimiento de Milicias de Niebla (Bedia y Carrasco, 1987a).
Junto a los restos de lo que debió ser la Torre Mayor son claramente perceptibles sobre el terreno los restos de un patio porticado central, rodeado de cuatro crujías y defendido por una muralla en la que sobresale la Torre Mayor de tapial, una planta que presenta muchas semejanzas con otros castillos/palacios cercanos, como el Castillo de San Pedro en Huelva o el alcázar de Niebla (Carriazo y Cuenca, 2004, 194).

En las encuestas enviadas a Gibraleón a partir de 1785 para la elaboración del Diccionario de Tomás López, se nos especifican algunos aspectos importantes sobre el castillo:”...en lo antiguo tuvo esta villa un castillo a la orilla del pueblo, en la parte que mira a poniente e inmediato al río Odiel, que corre de norte a sur y pasa inmediato al pueblo. Y hoy en el dicho castillo se ha construido un suntuoso palacio a expensas del excelentísimo Señor Duque de Béjar (que en gloria haya) cuando vivía en esta villa para habitación de su Excelencia y familia, en que es bastante capaz. Tiene un hermoso jardín poblado de muchos naranjos, limoneros y otros árboles, y varias plantas de flores que lo hacen agradable, y una cañería que a su costa hizo el dicho Señor Excelentisimo trayendo el agua por atanadores por debajo de tierra para proveerse dicho palacio y regar el jardín, cuya caja de agua está a medio cuarto de legua de esta villa, siendo su manantial tan perenne y abundante que no sólo provee dicho palacio sino a el Convento del Carmen de religiosas carmelitas de esta villa. Y con el agua sobrante riega una huerta que tiene pegada a sus muros, como también provee dicha cañería al convento de monjas dominicas de esta villa de dicha agua, y el sitio público de esta villa tiene un pilar para el avío de sus vecinos y dar agua a sus ganados, siendo abundante dicho manantial que, no pudiendo sorber los atanores cuanta agua le viene, tiene formado dicha caja o depósito de las aguas un ladrón por donde desagua la mucha que le entra a dicha caja de agua, y con ella muelen tres molinos, aunque ya los dos no están en uso por haberlos arruinado las avenidas de dicho arroyo....”. La parte más antigua de la población la ubica en el Barrio del Otero:” Asimismo, tiene esta villa dos parroquias, la mayor y más antigua tiene por titular al Señor San Juan Bautista, cuya iglesia estaba fundada en lo antiguo en el barrio del Otero..."(Sánchez, 1999, 121).

Con estas respuestas a la encuesta sobre Gibraleón se acompaña un dibujo en el que se indica la situación de los principales monumentos, entre ellos 
el "Palacio de la Duquesa", en el que se distingue su puerta y un edificio terminado en cúpula.

Según P. Madoz en Gibraleón se conservaban en su tiempo dos fortalezas, una situada al oeste y otra al norte, que correspondería al Castillo de Gibraleón, que asignó a la casa de la Cerda y a los Duques de Béjar. Todavía en estos años era navegable el Odiel hasta Gibraleón, donde llegaba la influencia de la marea alta y se podían pescar lisos e incluso sábalos. El vado se realizaba por el puente bajo de la Azua (Madoz, 1847).

CERÁMICAS ISLÁMICAS DEL CASTILLO DE GIBRALEÓN.

El material cerámico que vamos a presentar a continuación procede de la intervención arqueológica efectuada en el Castillo de Gibraleón (Huelva) por Juana Bedia García y Mª Jesús Carrasco Martín en 1985. Esta intervención tuvo carácter de urgencia y estuvo motivada por el interés del Ayuntamiento de Gibraleón para que se declarara a este inmueble como Bien de Interés Cultural con la categoría de Zona Arqueológica (Bedia y Carrasco, 1987a).

Previamente a la excavación arqueológica se realizó una prospección geofísica, para determinar la existencia de estructuras soterradas y la posibilidad de su lectura con relación a los distintos episodios de ocupación del sitio, efectuada por el grupo de geofísica del entonces Colegio Universitario de La Rábida. Los trabajos de excavación se repartieron en tres áreas del recinto intramuros, en las que se trazaron tres zanjas en las zonas en las que los trabajos de geofísica habían encontrado una resistividad más acentuada. Interesó especialmente el área más baja del solar, el Área II, que había quedado convertida en un erial, ya que la zona alta, el Área I, comprendía los restos del antiguo Palacio de los
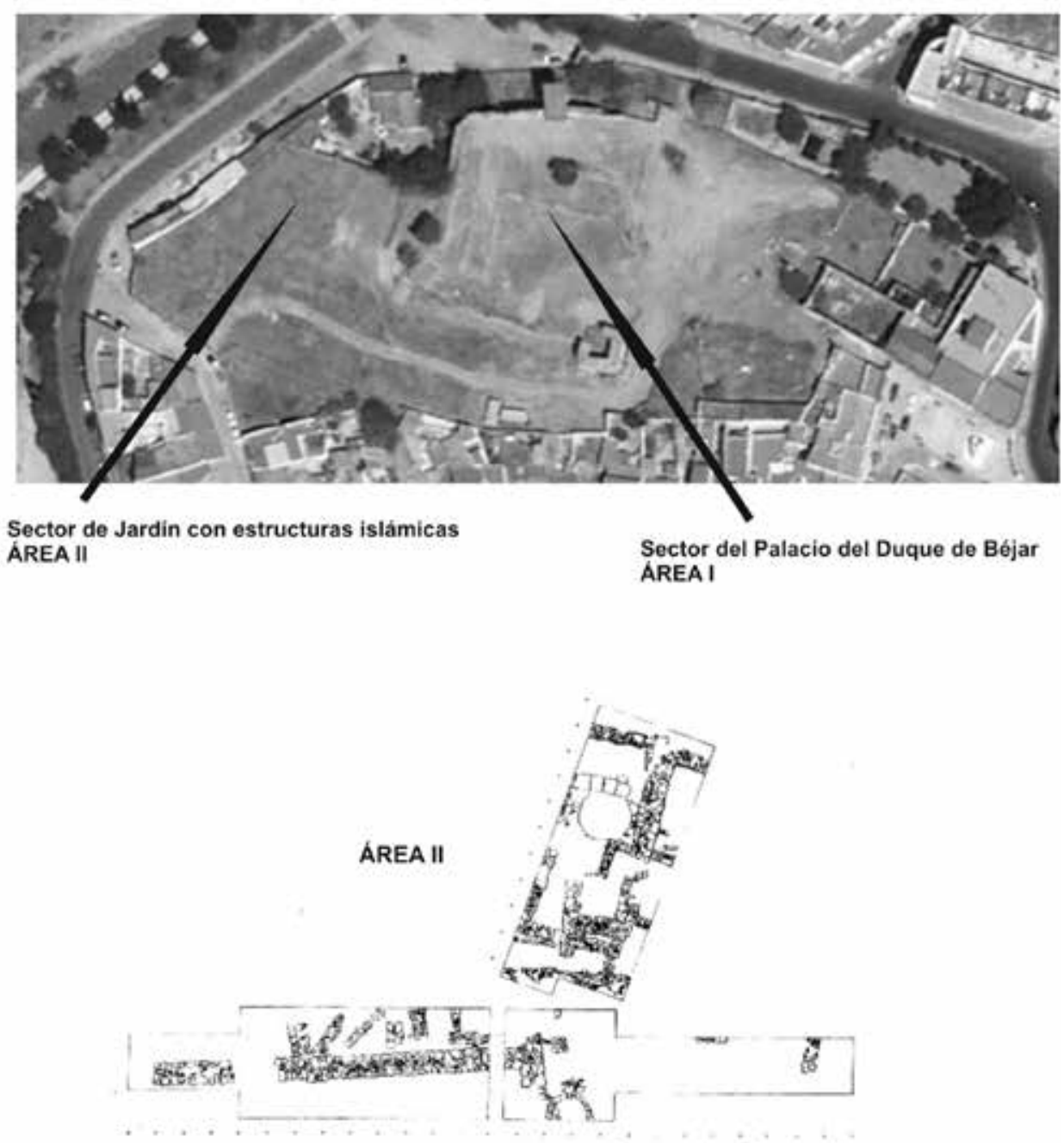

Figura 2. Áreas de excavación en el Castillo de Gibraleón. 
Duques de Béjar (figura 2). En el Área III, en la zona donde se conserva un paño de cerca de tapial con dos torres del primitivo recinto islámico, no se pudieron realizar cortes estratigráficos debido al peligro de ruina en que se encontraban estos restos por la proximidad de un grupo de casas que se adosaban a la línea de muralla. El método de trabajo consistió en la excavación de capas artificiales de no más de $15 \mathrm{~cm}$ de espesor hasta levantar el nivel superficial.

En el Área I (Palacio de los Duques de Béjar) la labor arqueológica se limitó a una limpieza superficial en aquellas zonas donde se apreciaban restos de tapial, y a través de este elemento pudieron localizarse los muros correspondientes al antiguo alcázar ducal, con el que también se relaciona una torre de gran porte que se encuentra intramuros (Torre del Homenaje), en la parte suroeste del recinto.

Desde el punto de vista de la ocupación del sitio, los restos más importantes se documentaron en el Área II (figura 2), donde la geofísica ofreció también los mejores resultados. Se trazó primero la Zanja A, que tenía unas dimensiones de 26 por 2 $\mathrm{m}$, en la que se localizaron las estructuras de más envergadura. Primero se levantó un primer nivel, de alteración superficial, que alcanzaba en algunos puntos los $0,80 \mathrm{~m}$ de potencia. A partir de este nivel se distinguió un segundo nivel, en el que fueron apareciendo los muros de las estructuras, y no se diferenciaron nuevos niveles hasta la base de esas estructuras, que apoyan directamente sobre el sustrato de pizarra, en el que se había excavado un pequeño pozo con brocal de lajas. Entre esas estructuras destaca un muro de unos $15 \mathrm{~m}$ de longitud, 0,85 $\mathrm{m}$ de anchura y una altura conservada de unos 1,60 $\mathrm{m}$. Para documentarlo al completo se ampliaron dos cuadrículas, A-2/S y A-2/N. Todos los materiales de este nivel de colmatación corresponden al momento de abandono del hábitat intramuros, y su cronología islámica nos lleva a considerar que después de la conquista cristiana este sector del castillo no volvió a ser ocupado.

En el Área II se trazó otra zanja, la Zanja B, de 10 por $2 \mathrm{~m}$, en perpendicular a la primera, que también se amplió con el cuadro B-1, en la que siguieron apareciendo estructuras, de difícil interpretación. En ellas sobresalía una fuente enfoscada en rojo a una profundidad de $-1,85 \mathrm{~m}$. En uno de los espacios definidos por las estructuras, la habitación $\mathrm{H}-1$, se localizó una de las piezas más interesantes de la excavación, un anafe con decoración estampi- llada. En esta zanja B existía un tercer nivel, más compacto y de coloración castaña. En este nivel se excavó una estructura semicircular de sillares rectangulares de caliza, cuyo diámetro alcanzó 1,50 $\mathrm{m}$, rodeada por un pavimento de mortero de cal de unos $8 \mathrm{~cm}$ de espesor, y bajo este pavimento una atarjea de ladrillos que se relacionó con la fuente.

En esta misma área se excavó una tercera zanja, Zanja C, de 10 por $1,5 \mathrm{~m}$, en la que se descubrió otra estructura, un horno cerámico de planta circular excavado en el propio substrato.

También se trazó un cuadro entre las áreas I y II (Cuadro D), con unas dimensiones de 3 por $3 \mathrm{~m}$, en el que también se documentaron estructuras, pero dado lo reducido del área excavada no pudieron ser interpretadas.

En el informe de la excavación se concluye que entre las formas cerámicas predominan los cuencos, cazuelas, jofainas, alcadafes, ataifores, marmitas, candiles, jarras, y trípodes, todas ellas de cronología almohade y en relación estratigráfica con las estructuras exhumadas en las Zanjas A, B y en sus ampliaciones. Dentro de este conjunto se prestó especial atención al anafe, a las cazuelas de costillas verticales y a los candiles (Bedia y Carrasco, 1987b).

Para la descripción de las distintas series cerámicas vamos a seguir la propuesta realizada por J. Navarro Palazón (1986).

1. Vajilla de COCINA PARA LA PREPARACIÓN DE ALIMENTOS.

\subsection{Marmita.}

-Marmita de cuerpo ovoide, cuello estrangulado y borde saliente (figura 3: 1).

Es un tipo de olla de cuerpo sencillo en la que, como señala M. Retuerce (1998), su principal atributo es su cuello curvo y borde exvasado. Es una forma con claros precedentes en épocas romana y visigoda, y por tanto muy corriente en los yacimientos emirales y califales, como se constata en Córdoba (Fuertes Santos, 2002) y Mérida (Alba y Feijoo, 2003).

En la provincia de Huelva es el tipo más representativo de los yacimientos emirales-califales, como el Llano de la Torre en Aroche (Pérez Macías, 1989; Fernández Gabaldón, 1992), y taifa, como el Cabezo de la Mina en Lucena del Puerto (Pérez Macías, 2002c) y la propia Niebla (Beltrán Pinzón, 2007).

-Marmita de cuerpo ovoide y borde escalonado al exterior (figura 3: 2 y 3). 


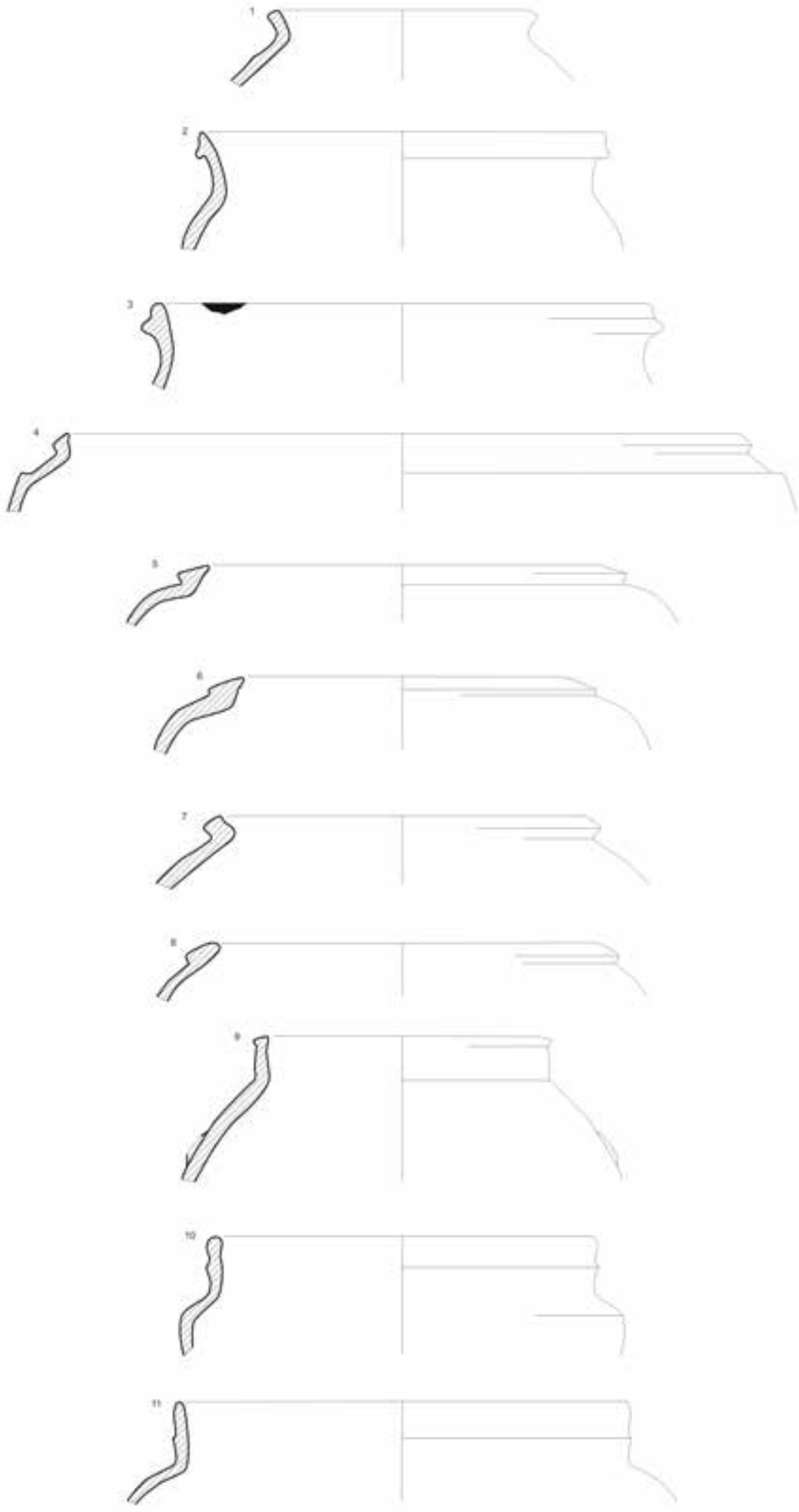

Figura 3. Marmitas.

Revista ONOBA, 2014, No 02 
Es una forma de cronología antigua que ha sido diferenciada en el tipo F.04 de Retuerce Velasco (1998), aunque en algunos asentamientos andaluces se mantiene hasta época almohade (Salinas Pleguezuelo, 2008).

-Marmita de cuerpo globular, carena alta y borde biselado (figura 3: 4).

Es la típica marmita con cuello en escotadura en la denominación de Retuerce Velasco (1998, 283 y ss.), quien las considera uno de los tipos más representativos de la cerámica islámica de la Meseta. En el cuadro de su dispersión Retuerce apunta a su amplia representación en toda la geografía de al-Andalus, Alicante, Valencia, Baleares, Almería, Extremadura, etc. Propone una cronología que se inicia a partir de precedentes en época visigoda, y se desarrolla en momentos emirales y califales en la Meseta, desde donde se extendería a otras áreas, hasta que a lo largo del siglo XI se generaliza al resto de al-Andalus, y solo perduraría en el siglo XII en el suroeste peninsular. En la zona de Niebla no aparece en contextos califales-taifas, como los de Cabezo de la Mina (Pérez Macías, 2002c) o el barrio de la Muralla del Desembarcadero (Beltrán Pizón, 2007), se hacen corrientes en el siglo XII, como el conjunto cerrado de Plaza de Santa María (Benabat y Pérez, 2003), y no forman parte de los repertorios almohades del relleno de la azotea de la Puerta de Sevilla (Campos, Gómez y Pérez, 2007). En Mértola se fechan en el siglo XII (Macías, 1992; Gómez Martínez, 2004). En el suroeste aparecen también en las alquerías de Belbí, Buenavista y Huerta Vieja en Bonares (Pérez Macías, 2002a), Sevilla (Huarte Cambra, 2002), Setefilla (Kirchner, 1990), Montorcaz (Schattner, Ovejero y Pérez, 2010), Córdoba (Salinas Pleguezuelo, 2012),y Cádiz (Cavila Sánchez-Molero, 2005). Son corrientes también en las provincias de Jaén (Choclán y Castillo, 1991) y Badajoz (Valdés Fernández, 1985).

Es probable que a este tipo correspondan los bordes salientes biselados al exterior (figura 3:7), un perfil que se documenta en la Meseta en este tipo de marmitas en el subtipo F.02.K de Retuerce (1998), que aparecen en otros yacimientos del suroeste, como la Herrería de Bonares (Pérez Macías, 2002a) y Montorcaz (Schattner, Ovejero y Pérez, 2010).

-Marmita de cuerpo globular, cuello estrangulado y borde entrante engrosado de sección triangular (figura 3: 5 y 6).

Ejemplares de tipología similar aparecen en Santarem (Mendes et alii, 2002), Mértola (Torres et alii, 1991), Barrera (Pérez Macías, 2002a), Sevilla (Vera y López, 2005), Córdoba (Salinas Pleguezuelo, 2012), y Jerez de la Frontera (Montes y González, 1987), entre otros yacimientos.

-Marmita de cuerpo ovoide, cuello estrangulado moldurado y labio engrosado al exterior (figura 3: 9). Pasta rojizas o de tonos anaranjados. Sin tratamiento, solo conserva en algunos puntos la superficie ahumada como consecuencia de su exposición al fuego.

Es la forma predominante en los contextos almohades del suroeste peninsular, y puede presentar ligeras variantes, de las cuales en Saltés se han establecido cuatro subtipos (Bazzana y Bedia, 2005). Aparece en todos los yacimientos del sur de Portugal y Andalucía, en Palmela (Ferreira, 2004), en Mértola corresponde al tipo 7 (Gómez Martínez, 2004), Silves (Varela Gomes, 1988), Tavira (Cavaco y Covaneiro, 2010; Diniz, Covaneiro y Cavaco, 2012), Salir (Catarino, 2000), Loulé (Luzia, 2003), en Niebla (Campos, Gómez y Pérez, 2006), en sus alquerías periurbanas (Benabat y Pérez, 1999) y en las de su demarcación, entre ellas en la Barrera y la Herrería de Bonares (Pérez Macías, 2002a) y en la Rotura I en Rociana del Condado (Pérez Macías, 2002b), Castillo de Aracena (Romero. Rivera y Pérez, 2012), en la cora de Sevilla en Alcalá de la Alameda en Chucena (Perez Macías, 2011), en el Cortijo del Vico de Aznalcázar (González, Pérez y García, 2009), Montorcaz (Schattner, Ovejero y Pérez, 2010), Setefilla (Kirchner, 1990), Córdoba (Salinas Pleguezuelo, 2012), Mesa de Chiclana (Fernández Barba, 2012), Puerto de Santa María (Giles y Mata, 2001), Pocito Chico (Ruiz y López, 2001), Jerez de la Frontera (Montes y González, 1987), y Cádiz (Cavila Sánchez-Molero, 2005). Fuera de esta área son también corrientes en el sureste, en el área murciana (Navarro Palazón, 1991), mientras en otras zonas predominan las formas de cuellos cilíndricos sencillos, sin el borde indicado, como los ejemplares de Calatrava la Vieja en la Meseta (Retuerce Velasco, 1998).

-Marmita de cuerpo globular y borde entrante engrosado al exterior (figura 3: 8).

En Mértola se considera una forma tardía (Gómez Martínez, 2004), que podría situarse en época almohade en función de sus paralelos en Jerez de la Frontera (Fernández Gabaldón, 1987).

\subsection{Cazuela.}

-Cazuela de cuerpo hemisférico y borde redondeado inclinado al exterior (figura 4: 2 y 3). Es una 

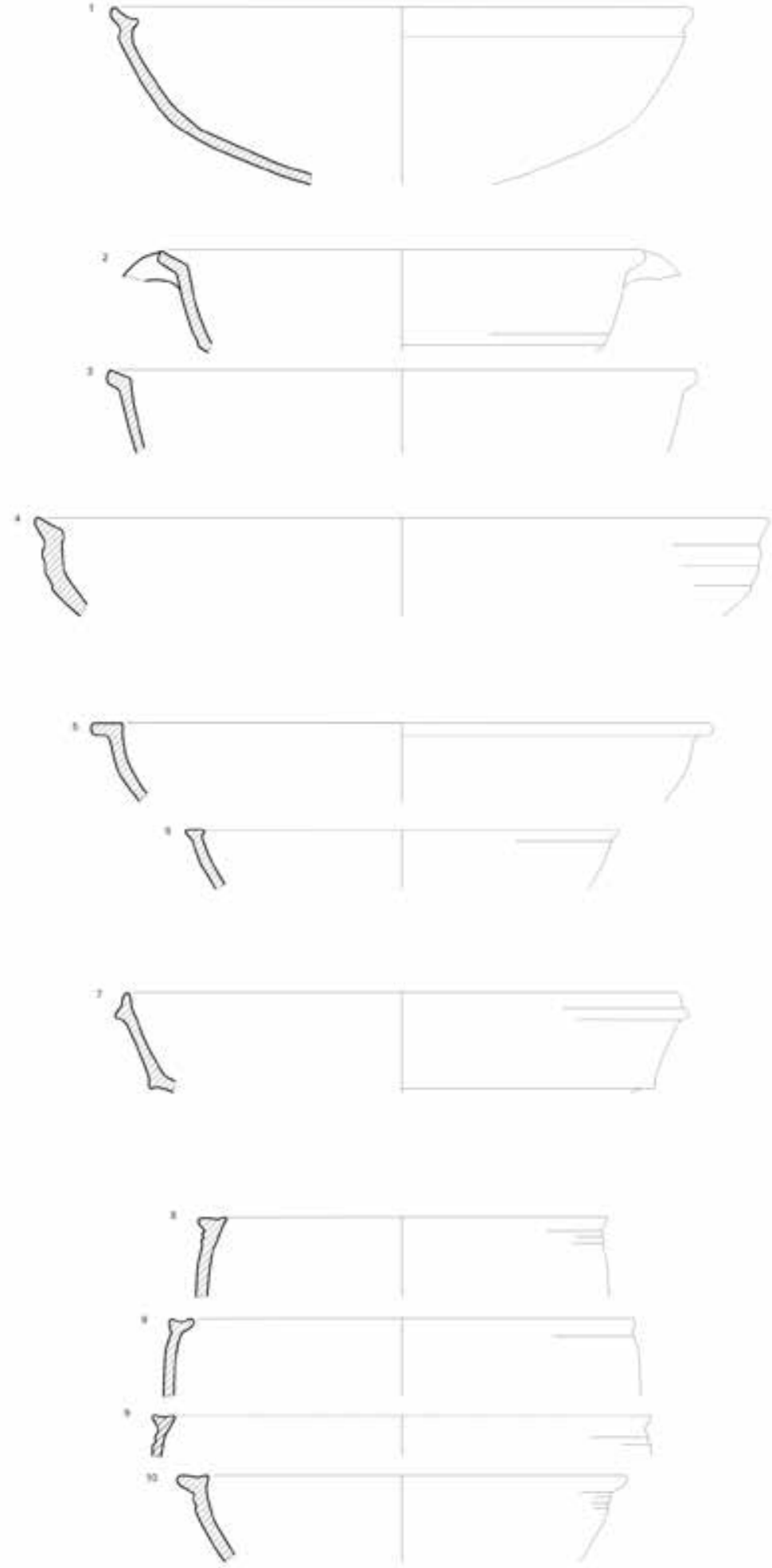

Figura 4. Cazuelas.

Revista ONOBA, 2014, No 02 

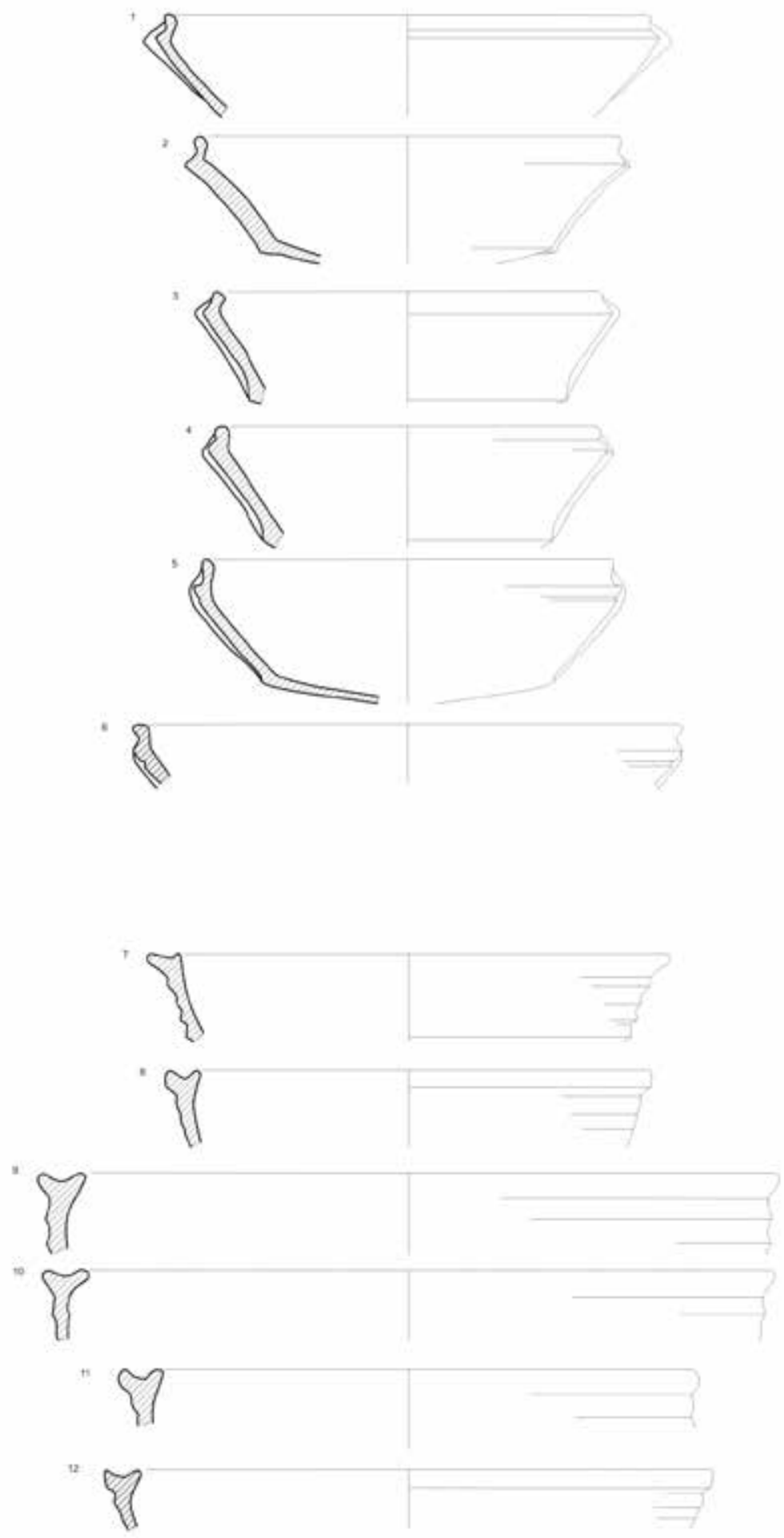

Figura 5. Cazuelas. 
forma que ha sido considerada tardoalmohade en Castillejo de los Guajares (Cressier et alii, 1991) y Murcia (Navarro Palazón, 1986).

-Cazuela de cuerpo hemisférico moldurado y borde apuntado biselado al interior (figura 4: 4). Es un tipo de cazuela con paralelos en Faro (Paulo, 2000), Mértola (Gómez Martínez, 2004), Saltés (Bazzana y Cressier, 1989), en las alquerías de Huerta Vieja y La Suerte en Bonares (Pérez Macías, 2002a), Niebla (Benabat y Pérez, 2003), Sevilla (Huarte Cambra, 2002), y Mesa de Chiclana (Fernández Barba, 2012). En Mértola y Saltés se fechan en época almohade.

-Cazuela de cuerpo hemisférico y borde vuelto horizontal (figura 4:5). Un ejemplar de sección casi completa de este tipo de cazuela se conoce en la Barrera de Bonares (Pérez Macías, 2002a).

-Cazuela de cuerpo troncocónico y borde plano indicado al interior y exterior (figura 4:6). Ejemplares de idéntica tipología se encuentran en la alquería de Belbí, cuyos materiales pueden fecharse en los siglos XI y XII (Pérez Macías, 2002a).

-Cazuela de borde escalonado al exterior (figura 4: 1 y 8 a 10). Es un tipo de cazuelas para las que no hemos encontrado paralelos exactos, aunque por su forma podría encuadrarse en el tipo siguiente, las de borde bífido para recibir tapadera. Destacan, no obstante, por su pequeño formato.

-Cazuela de borde bífido (figura 5: 7 a 12). Es una forma que aparece ya en momentos omeyas en la Meseta, donde Retuerce la define en su tipo G.04 (Retuerce Velasco, 1998), y se encuentran también en el periodo africano en el área levantina (Azuar Ruiz, 1989).

En el suroeste la encontramos en Niebla (Pérez y Bedia, 1993) y en otros asentamientos de Andalucía occidental, en Sevilla (Pleguezuelo y Lafuente, 1995), Córdoba (Salinas Pleguezuelo, 2012), Jerez de la Frontera (Fernández Gabaldón, 1987), Cádiz (Cavila Sánchez-Molero, 2005), y Mesa de Chiclana (Ramos et alii, 2001; Fernández Barba, 2012).

-Cazuelas de costillas (Figura 5:1 a 6). Es un tipo ampliamente documentado en el oeste peninsular en contextos almohades y tardo-almohades, de la segunda mitad del siglo XII y primera mitad del siglo XIII. Sus bordes suelen ser redondeados, verticales o ligeramente entrantes, con carena superior, y el fondo suele ser convexo a partir de una carena en el tercio inferior del cuerpo. Su elemento más característico son los nervios verticales que adornan el exterior de su cuerpo, desde la carena próxima al borde hasta el arranque de la carena que marca el comienzo del fondo. Sus pastas suelen ser anaranjadas o rojizas, de atmósferas oxidantes, de exteriores ahumados por el contacto con el juego durante la cocción de los alimentos. Están vidriados con cubiertas transparentes de tono melado en el interior, que pasa en algunas zonas al exterior.

Sus paralelos se extienden desde Alentejo, Algarve, Huelva, Sevilla, Badajoz, Córdoba y Cádiz, Alcácer do Sal (Carvalho y Faria, 1994), Aljustrel (Estorninho, Martins, Ramos, y Muralla, 1994), Aljezur (Silva y Gomes, 2002), Mértola (Gómez Martínez, 2004), Faro (Gonçalves y Silva, 2009), Silves (Varela Gomes, 1998), Salir (Catarino, 2000), Tavira (Cavaco y Covaneiro, 2010; Diniz, Covaneiro y Cavaco, 2012), Cacela Velha (Alvaro Sánchez, 2000), Saltés (Bazzana y Cressier, 1989; Bazzana y Bedia, 2005), Niebla (Campos, Gómez y Pérez, 2006), la Barrera y la Herrería en Bonares (Pérez Macías, 2002), Castillo de Aracena (Romero, Rivera y Pérez, 2012), Cuatrovita (Valor Piechotta, 1982), Sevilla (Pleguezuelo y Lafuente, 1995; Huarte Cambra, 2002), Montorcaz (Pérez, Ovejero y Schattner, 2008), Setefilla (Kirchner, 1990), Cote (Valor et alii, 2001), Estepa (Juárez Martín, 1999), Cádiz (Cavila Sánchez-Molero, 2005), Pocito Chico en Puerto de Santa María (Ruiz y López, 2001), la Mesa de Chiclana (Fernández Barba, 2012), y Vejer de la Frontera (Molina Carrión, 1993). También se ha señalado su presencia en Aznalcóllar (Hunt Ortiz, 1999), Benaocaz (Alarcón et alii, 1993), y Cabezo de Hortales (Jiménez et alii, 2001). Fuera del área meridional aparecen en Badajoz (Valdés et alii, 2001) y Calatrava la Vieja (Retuerce Velasco, 1998).

\section{VASIJA PARA LA PRESENTACIÓN DE ALIMENTOS.}

\subsection{Ataifor.}

-Ataifor hemisférico de borde saliente (figura 6: 1 a 7 ). Se considera que es una forma influenciada por los modelos chinos y fatimíes de reflejo dorado, y tiene una larga perduración, desde fines del siglo $\mathrm{X}$ hasta época almohade, con diverso tipo de decoraciones, desde el verde y morado, blanco y verde, reflejo dorado, hasta las cubiertas transparentes de tono melado como nuestros ejemplares.

Sin ánimo de hacer numerosos sus paralelos tipológicos, en contextos del siglo XII-XIII se documentan Mértola (Gómez Martínez, 2004), Silvés (Gomes, 1988), Cerro da Vila (Martins de Matos, 1991), Tavira (Cavaco y Covaneiro, 2010), Vale do 

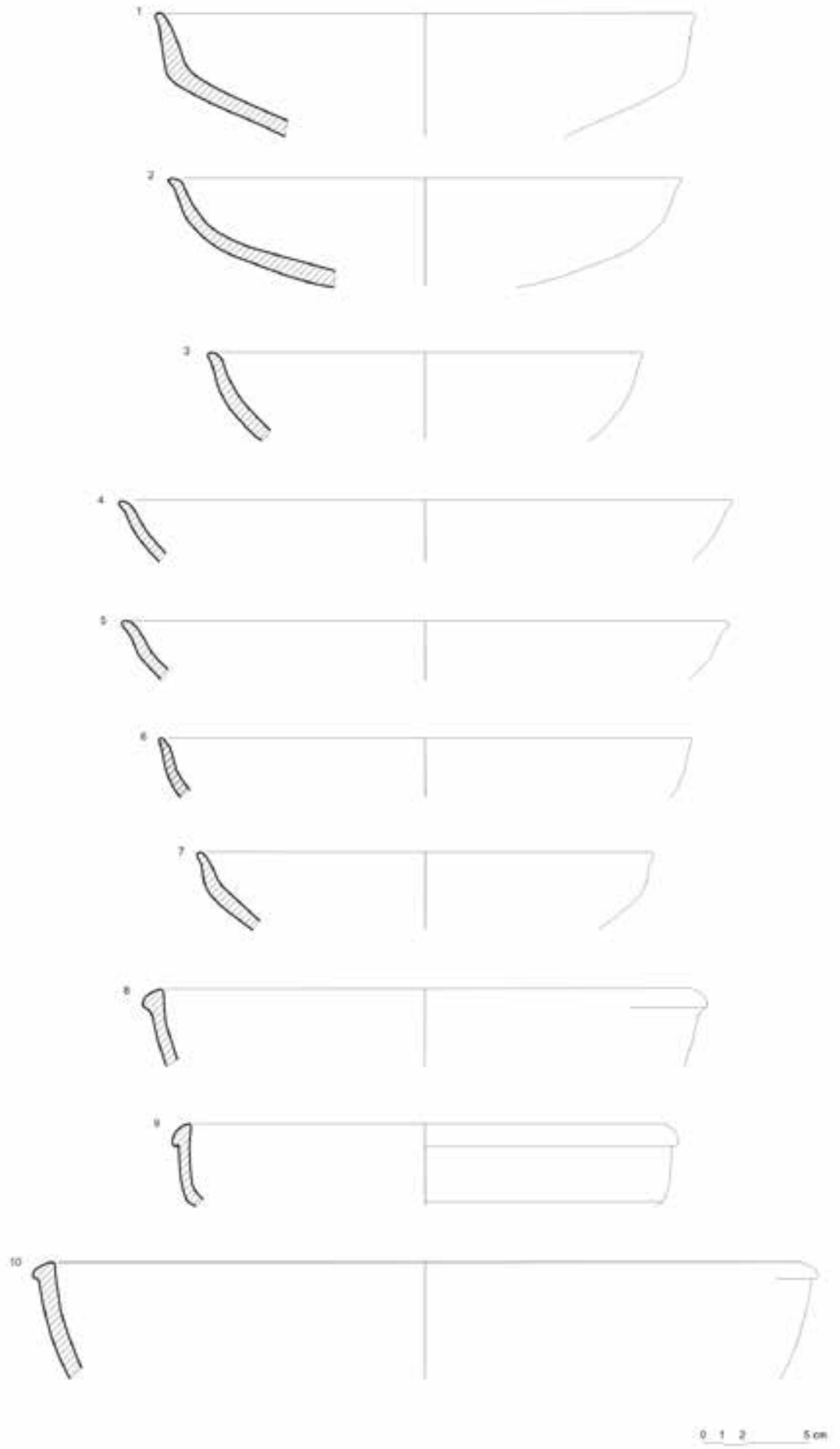

Figura 6. Ataifores.

REvista ONOBA, 2014, No 02 

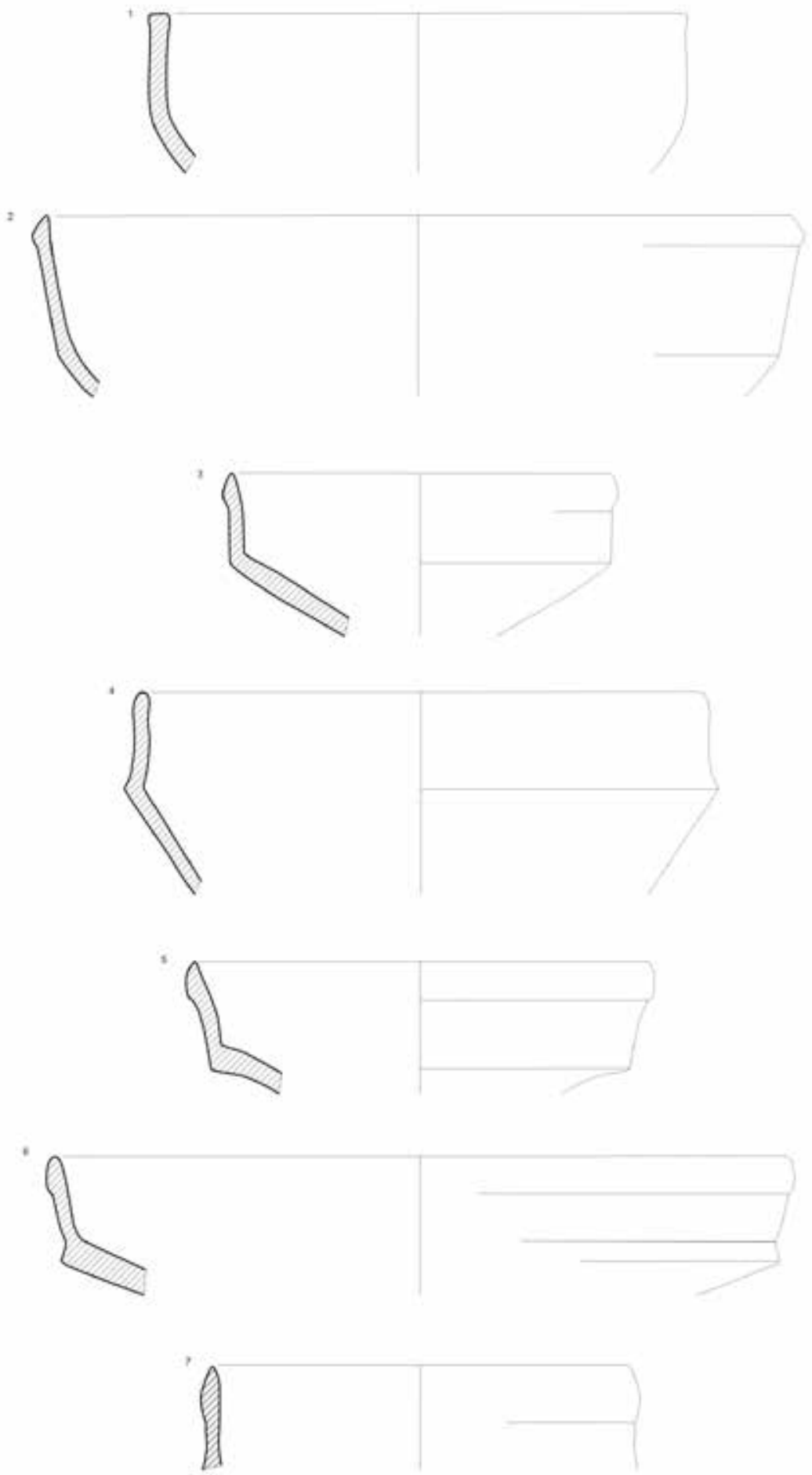

Figura 7. Ataifores.

Revista ONOBA, 2014, No 02 
Boto (Catarino, Arruda y Gonçalves, 1981), Niebla (Benabat y Pérez, 2003), Saltés (Bazzana y Bedía, 2005), en Rotura III, Vallelejo I y Vallelejo II en Rociana del Condado (Pérez Macías, 2002b), Almonaster la Real (Romero, Rivera y Pérez, 2012), y Setefilla (Kirchner, 1990).

-Ataifor hemisférico de borde engrosado al exterior (figura 6:8 a 10).M. Retuerce lo considera una forma a caballo entre los tipos II y IV de Roselló Bordoy, y lo documenta en todas las áreas de dominio almohade, Valencia, Baleares, Murcia, en el Valle del Guadalquivir, Guadiana, y Algarve. En el sur peninsular se encuentra en Jerez de la Frontera, Beca, Saltés, Mértola y Silves. Según su cronología en Calatrava la Vieja establece su data entre los siglos XII y XIII (Retuerce, 1998, 117).

-Ataifor de cuerpo carenado (figura 7:1 a 5). Entran dentro del tipo II de la serie ataifor de Roselló Bordoy. Según M. Retuerce es abundante en las provincias de Valencia y Alicante, aunque también se conocen ejemplares en la zona murciana y baleares. Distingue dentro del grupo variantes $(22,23$, 24 y 25), y su cronología la sitúa en la fase almohade, entre fines del siglo XII y principios del siglo XIII (Retuerce, 1998, 119).

No es muy abundante en el suroeste de al-Andalus, pero al tipo se acercan algunos ejemplares de Beca (Cavila Sánchez-Molero, 1992). Formas emparentadas son las catalogadas dentro del grupo 4 de ataifores de Mértola (Gómez Martínez, 2004) y algunos ejemplares de Faro (Gonçalves y Silva, 2009).

-Ataifor de carena acusada (figura 7:6). Ataifor con pie en anillo, parte inferior del cuerpo de forma tronco-cónica invertida, carena media de perfil acusado, parte superior del cuerpo de tendencia vertical, y borde engrosado al exterior. El tratamiento es uniforme en todos los ejemplares, cubierta vítrea transparente de tono melado tanto al interior como al exterior.

Es una forma típica del suroeste en época almohade, que aparece en Faro (Gonçalves y Silva, 2009), Mértola (Gómez Martínez, 2004), Silves (Gomes, 1988), Aljezur (Silva y Gomes, 2002), Tavira (Cavaco y Covaneiro, 2010), Saltés (Bazzana y Bedia, 2005), Castillo de Palos de la Frontera (Pozo, Campos y Borja, 1996), Niebla (Pérez y Bedia, 1993; Campos, Gómez y Pérez, 2006), en la Barrera y Herrería en Bonares (Pérez Macías, 2002a), en la Rotura I en Rociana del Condado (Pérez Macías, 2002b), en Cerro Salomón de Riotinto (Pérez Macías, 1999), en el Cortijo del Vico en Aznalcázar
(González, Pérez y García, 2009), Setefilla (Kirchner, 1990), en Montorcaz y Montegil en la Sierra Norte de Sevilla (Pérez, Ovejero y Schattner, 2008), en Puerto de Santa María (Giles y Mata, 2001), Pocito Chico en Puerto de Santa María (Ruiz y López, 2001), Cádiz (Cavila Sánchez-Molero, 2005), Mesa de Chiclana (Fernández Barba, 2012), y Barbesula (Cavilla Sánchez-Molero, 1990). Se ha señalado su cronología tardo-almohade, que marca la transición hacia los modelos de ataifor nazaríes (Cressier, Riera y Roselló, 1991).

Entre los fragmentos pertenecientes a ataifores sobresale un fragmento de pie en anillo con decoración geométrica de cuerda seca total muy mal conservada, en el que las líneas negras de separación de los colores de vidrio delatan el empleo de esta técnica decorativa. El motivo es similar al de algunos ataifores de Mértola con rosetas o flores de loto en planta con formas geométricas radiales (Gómez Martínez, 2004, 625). En opinión de S. Gómez Martínez, la cuerda seca total no es una técnica decorativa frecuente en el suroeste, aunque se han encontrado ejemplares en Moura (Macías, 1993), Noudar (Rego, 2003), y Évora (Teichner, 1994), y señala que los motivos son cercanos a los de la cuerda seca total de los ejemplares malagueños y almerienses. Su cronología la sitúa en el siglo XII, durante el dominio almorávide y justifica su abundancia en Mértola por su importante posición en el tráfico fluvial, que la comunicaría con los principales puertos mediterráneos, de donde procederían los ejemplares. También se han realizado hallazgos en otras ciudades importantes del suroeste, en Faro (Gonçalves y Silva, 2009) y Badajoz (Valdés et alii, 2001). Por tanto, no extraña tampoco que aparezca en Gibraleón, hasta donde en época islámica podían llegar los barcos, que debía desempeñar un papel relevante en el abastecimiento del mineral de hierro que llegaba a Saltés desde el distrito minero de Tharsis (Bazzana y Trauht, 1997).

Otro tipo de decoración en fondo de ataifor es un fragmento de solero con vedrío verde y decoración interior estampillada formando motivo circular (figura 15:2). Este tipo de decoración aparece en contexto almohades del suroeste peninsular en Silves (Gómes, 1988).

3. VAJILLA DE ALMACENAMIENTO, TRANSPORTE Y CONSERVACIÓN DE ALIMENTOS.

3.1. Jarros/jarritas/jarras.

- Jarros de cuello de tendencia cilíndrica (fig. 8:1). 

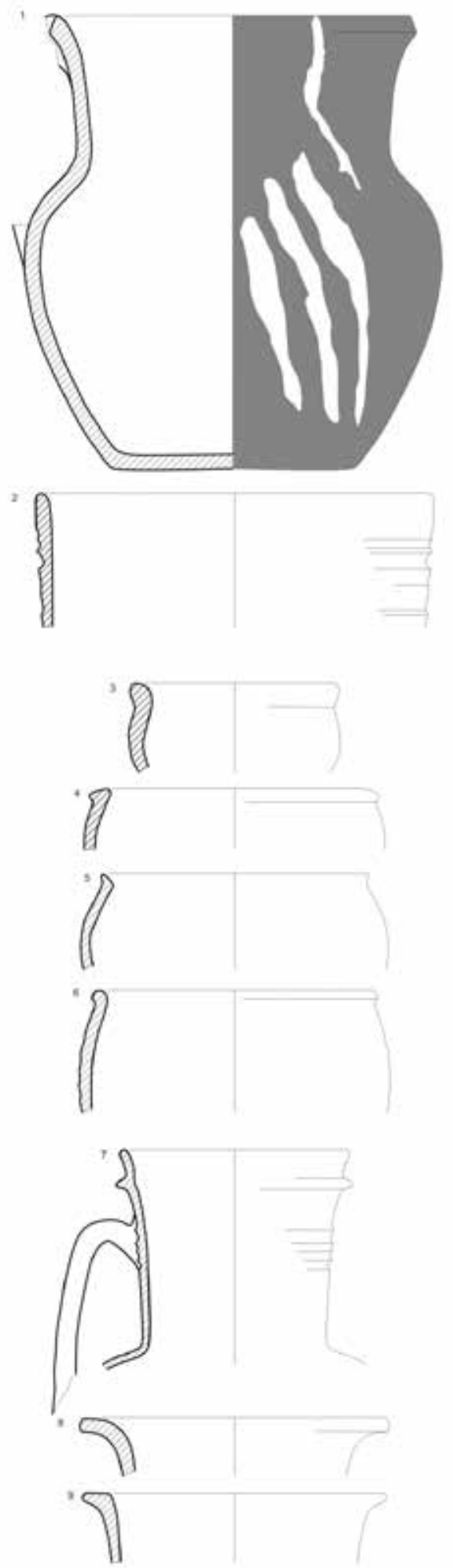

Figura 8. Jarras y Jarros.

Revista ONOBA, 2014, No 02 

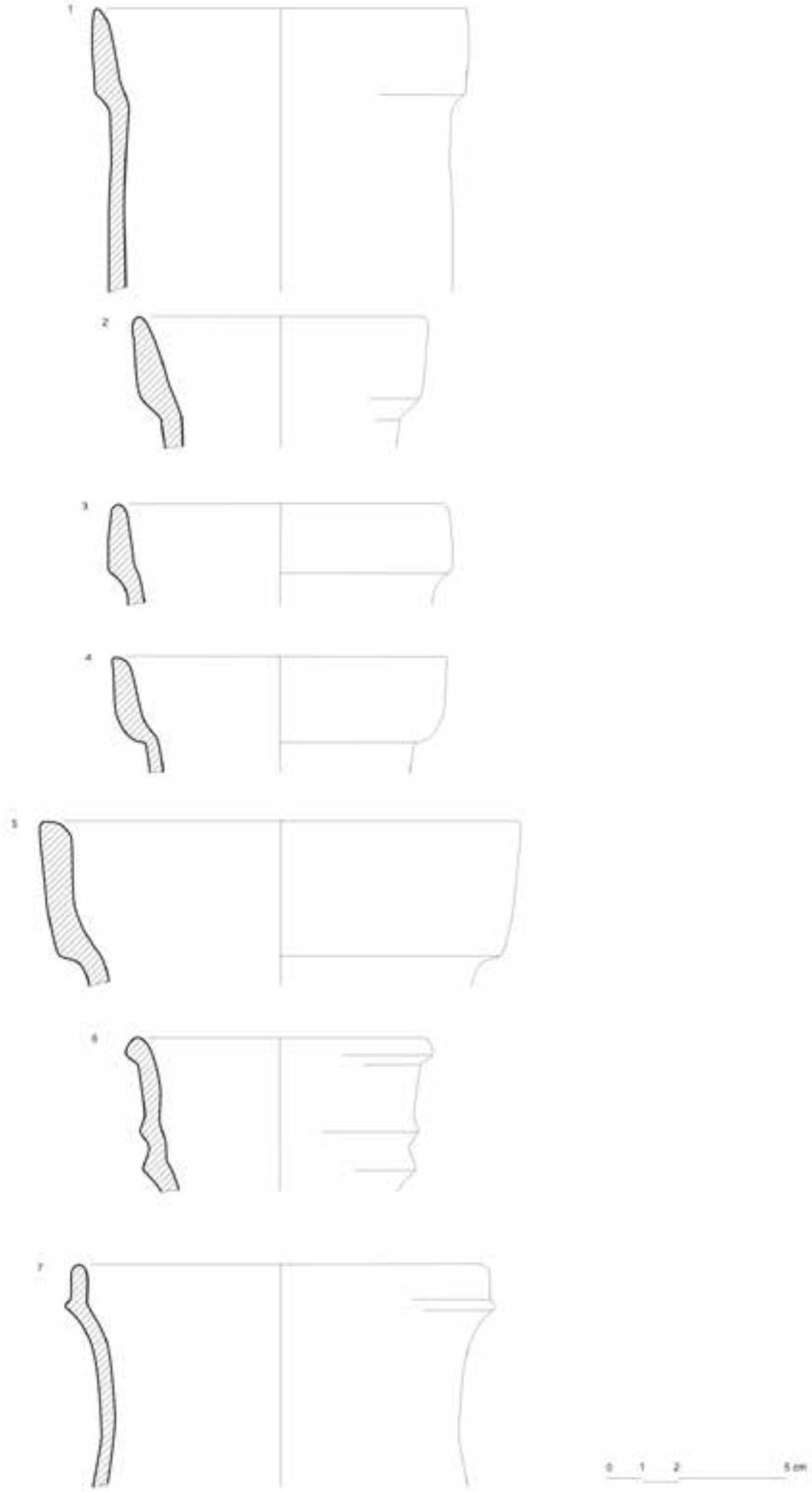

Figura 9. Jarras de acarreo. 
Es una forma que está presente desde época emiral en Córdoba (Fuertes Santos, 2002) y perdura hasta los siglos XII y primera mitad del XIII (Salinas Pleguezuelo, 2012). Es una forma característica de los repertorios cerámicos andalusíes, así entre otros lugares aparece en Sevilla (Huarte Cambra, 2002), Jerez de la Frontera (Montes y González, 1987), Calatrava la Vieja (Retuerce Velasco, 1998), Mértola (Gómez Martínez, 2004), etc. En general pueden estar pintadas con goterones de pintura roja, negra o blanca, como en nuestro caso.

- Jarros de cuello convexo (figura 8: 3 a 6). Es un tipo de jarro de menores dimensiones que los cántaros y las jarras de acarreo. Se conocen ejemplares similares en el yacimiento metalúrgico de Cabezo de la Mina en Lucena del Puerto, de los siglos X y XI d.C. (Pérez Macías, 2002c), pero perduran en el siglo XII según los ejemplares aparecidos en Cádiz (Cavila Sanchéz-Molero, 2005) y Mértola (Torres et alii, 2001)

-Jarras de cuello troncocónico (figura 8: 7).Se corresponde con el tipo C38c de la tipología de la cerámica islámica de la Meseta, cuyo ejemplar procede de Calatrava la Vieja, de cronología almohade (Retuerce Velasco, 1998). Tiene una gran dispersión, el área levantina (Azuar Ruiz, 1989) y murciana (Navarro Palazón, 1986), Mallorca (Roselló Bordoy, 1978), valle del Guadalquivir (Salinas Pleguezuelo, 2012), Algarve (Catarino, 1992), y Alentejo (Gómez Martínez, 2004).

- Jarras de cuello troncocónico y borde saliente (figura 8: 8 y 9). Recuerdan extraordinariamente a los bordes de jarras de época califal, como los de Llano de la Torre en Aroche (Pérez Macías, 1989;
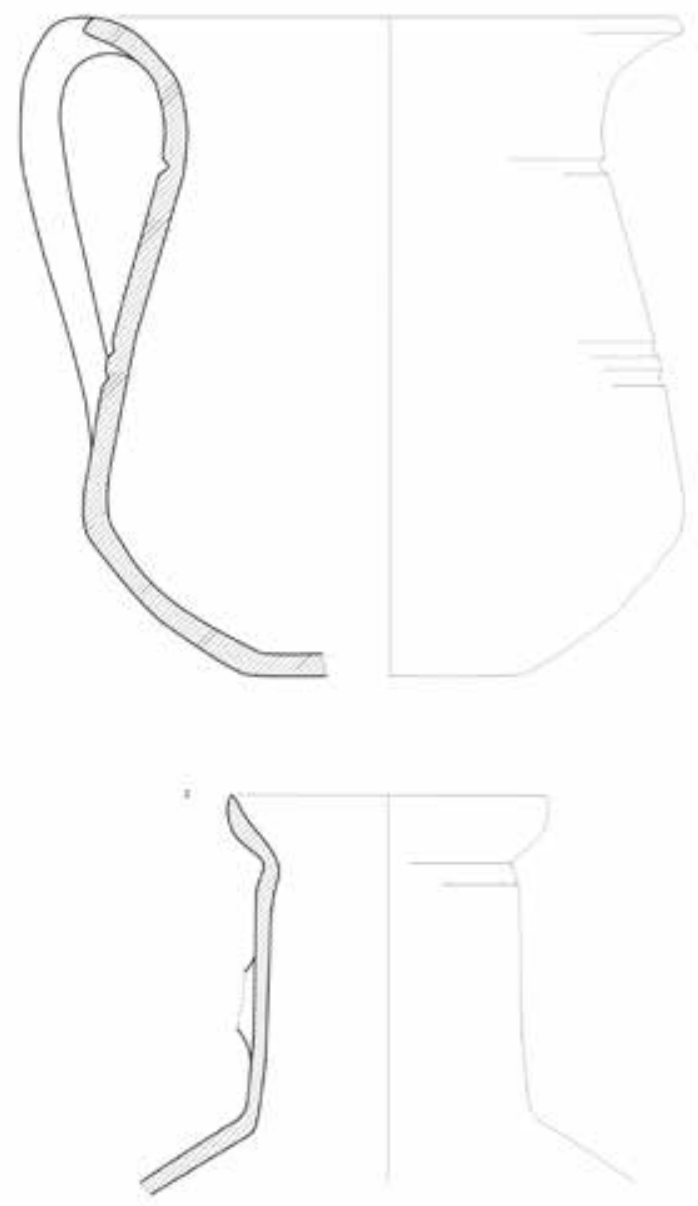

Figura 10. Jarros de boca lobulada. 
Fernández Gabaldón, 1992), asimilable al tipo I de los cántaros de Mértola (Gómez Martínez, 2004).

- Jarras de acarreo de borde diferenciado (figura 9:1 a 7$)$.

Se distinguen del tipo anterior por el cuello más estrecho y cilíndrico, y es constante su aparición en yacimientos almohades, con variadas maneras de rematar la embocadura y variada tipología de fondos, en Santarém (Mendes et alii, 2002), Mértola, los tipos 2D y 3 de Gómez Martínez (2004), Niebla (Belén y Escacena, 1992) y Jerez de la Frontera con ejemplares de asas de látigo y fondo cóncavo (Fernández Gabaldón, 1987), con el borde engrosado en Vejer de la Frontera (Molina Carrión, 1993), en ejemplares de la Meseta con el fondo convexo (Retuerce Velasco, 1998), y en los ajuares domésticos de Murcia en formas de fondo plano (Navarro Palazón, 1991).

- Jarros de boca trilobulada (figura 10).

Los jarros y jarritos de boca trilobulada son muy corrientes en época omeya, donde suelen ir decorados con pintura blanca, pero este tipo de recipientes de boca trilobulada, de formas más esbeltas, perduran en los siglos XII y primera mitad del siglo XIII. Se conocen ejemplares del siglo XI en Niebla (Beltrán Pinzón, 2007), del siglo XII en el arrabal del río de Mértola (Gómez y López, 2012), y de fines del siglo XII y comienzos del siglo XIII en Córdoba (Salinas Pleguezuelo, 2012), Sevilla (Vera y López, 2005), y Calatrava la Vieja (Retuerce Velasco, 1998).

- Jarro con pitorro vertedor (figura 3: 10 y 11).

Dos fragmentos de vasos de cuerpo globular y cuello cilíndrico moldurado entran en la tipología de este tipo de vasos, aunque no conservan el pitorro. Estos vasos fueron definidos como lecheras por Bazzana y Cressier (1989) en su estudio de las cerámicas de Saltés. A la geografía de su dispersión y cronología dedicó Cavila un primer trabajo, caracterizándolos como una forma típica del suroeste peninsular en época almohade, y confirmando su dispersión en Jerez de la Frontera, Torre de Doña Blanca, Beca, Bovedilla (Ubrique), y Sevilla (Cavila Sánchez-Molero, 1993). En el suroeste han aparecido ejemplares en Alcácer do Sal (Carvalho y Faria, 1994), Mértola (Gómez Martínez, 2004), Silves (Gomes, 1988), Saltés (Bazzana y Cressier, 1988), Niebla (Benabat y Pérez, 2003), Barrera y Herrería en Bonares (Pérez Macías, 2002a), y Purchena (Pérez y Serrano, 2004).

\subsection{Tinajas (figura 11: 8 y 9).}

No han sido abundantes los hallazgos de tinajas en el castillo de Gibraleón, y los dos ejemplares recuperados remiten a un mismo tipo de embocadura. Son de cuello cilíndrico, borde exvasado, probable cuerpo de tendencia ovoide, y base plana. Las pastas son de tonalidades blanquecinas o amarillento blanquecinas.

Es un tipo de tinaja que remite a tipologías almohades. En la provincia de Huelva este tipo de tinajas aparecen en las alquerías del alfoz de Niebla, la Barrera de Bonares (Pérez Macías, 2002a), Rotura II y Vallelejo en Rociana del Condado (Pérez Macías, 2002b), en el Cortijo del Vico de Aznalcázar (Gonzáles, Pérez y García, 2009), en las alquerías periurbanas de Huelva, en el Colegio Francés (Gómez, López y Beltrán, 2001) y en La Almagra (Vidal et alii, 2008). En contextos urbanos está constatada en Niebla, Saltés (Bazzana y Bedia, 2005), y Purchena en Chucena (Pérez y Serrano, 2004).También es corriente en los asentamientos portugueses, en Mértola (Gómez Martínez, 2004), y Silves (Gómes, 1988).

Asimismo han aparecido dos fragmentos de galbos estampillados pertenecientes a tinajas. A tenor de las dimensiones de las paredes sus medidas debieron ser más reducidas que la forma descrita anteriormente. Uno de ellos es un fragmento de pared con motivos fitomórficos estampillados y cubierta vítrea verde (figura 15: 5). El otro está estampillado al exterior con un motivo geométrico de un friso de rombos concéntricos delimitado por dos baquetones en relieve con una decoración de línea ondulada. Debe corresponder por el desarrollo de la sección a un cuerpo de tendencia globular. La decoración estampillada es una de las técnicas preferidas de decoración de las grandes piezas, como las tinajas. Retuerce considera que estas tinajas con decoración estampillada, con o sin vedrío verde, se encuentran en zonas de al-Andalus que conocieron la presencia almohade, y señala su ausencia en las comarcas situadas al norte del río Segura (Retuerce, 1998, 355).

Este tipo de tinajas estampilladas, con vidriado verde o sin vidriar, se encuentran bien representadas en la Alcáçoba de Mértola, donde se le atribuye una cronología almohade, de la segunda mitad del siglo XII y primera mitad del siglo XIII (Gómez Martínez, 2004, 290). Son corrientes en toda la geografía andalusí, en el suroeste, zona levantina y Baleares (Roselló Bordoy, 1978), y en el sureste 

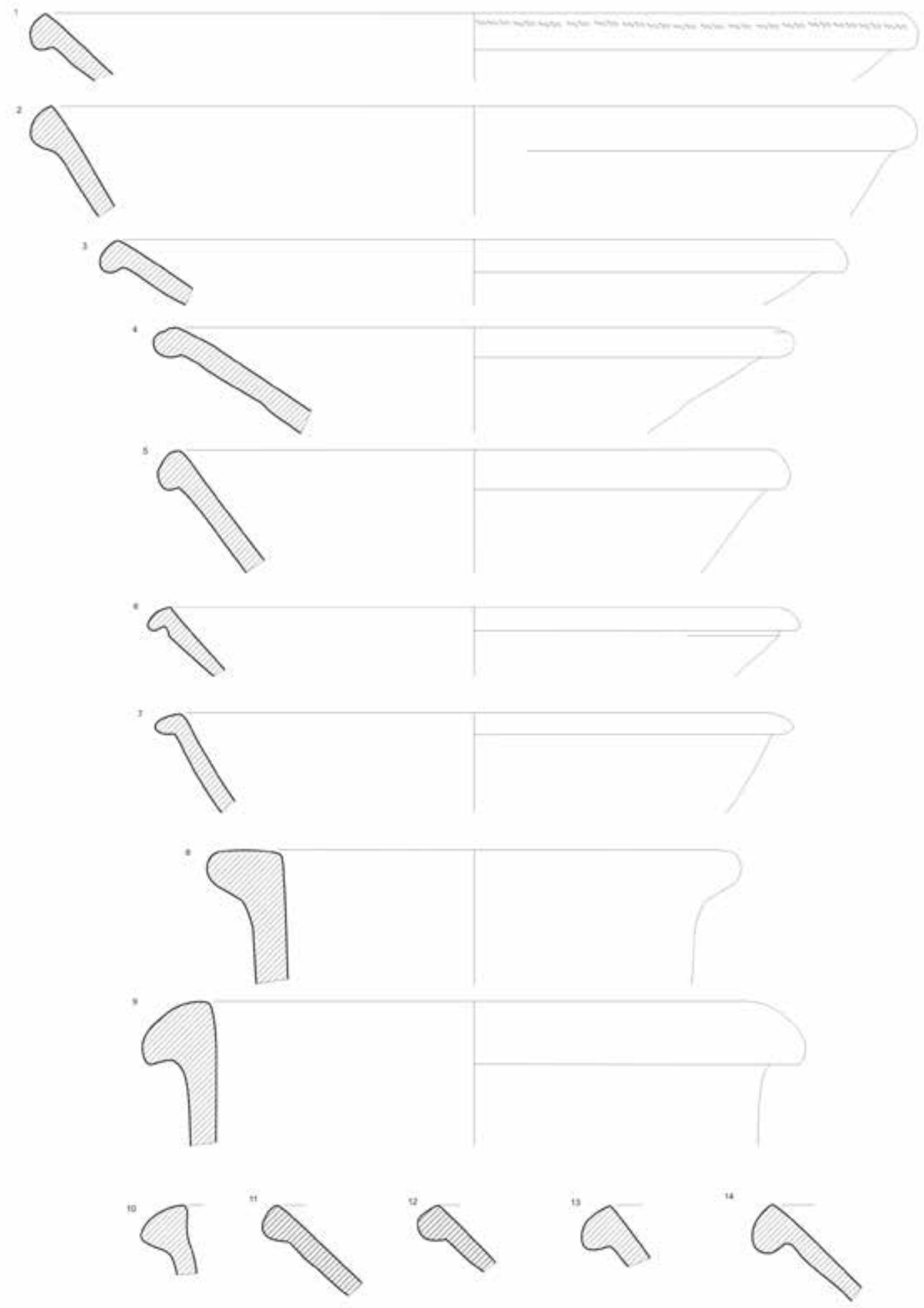

Figura 11. Alcadafes y tinajas.

Revista ONOBA, 2014, No 02 

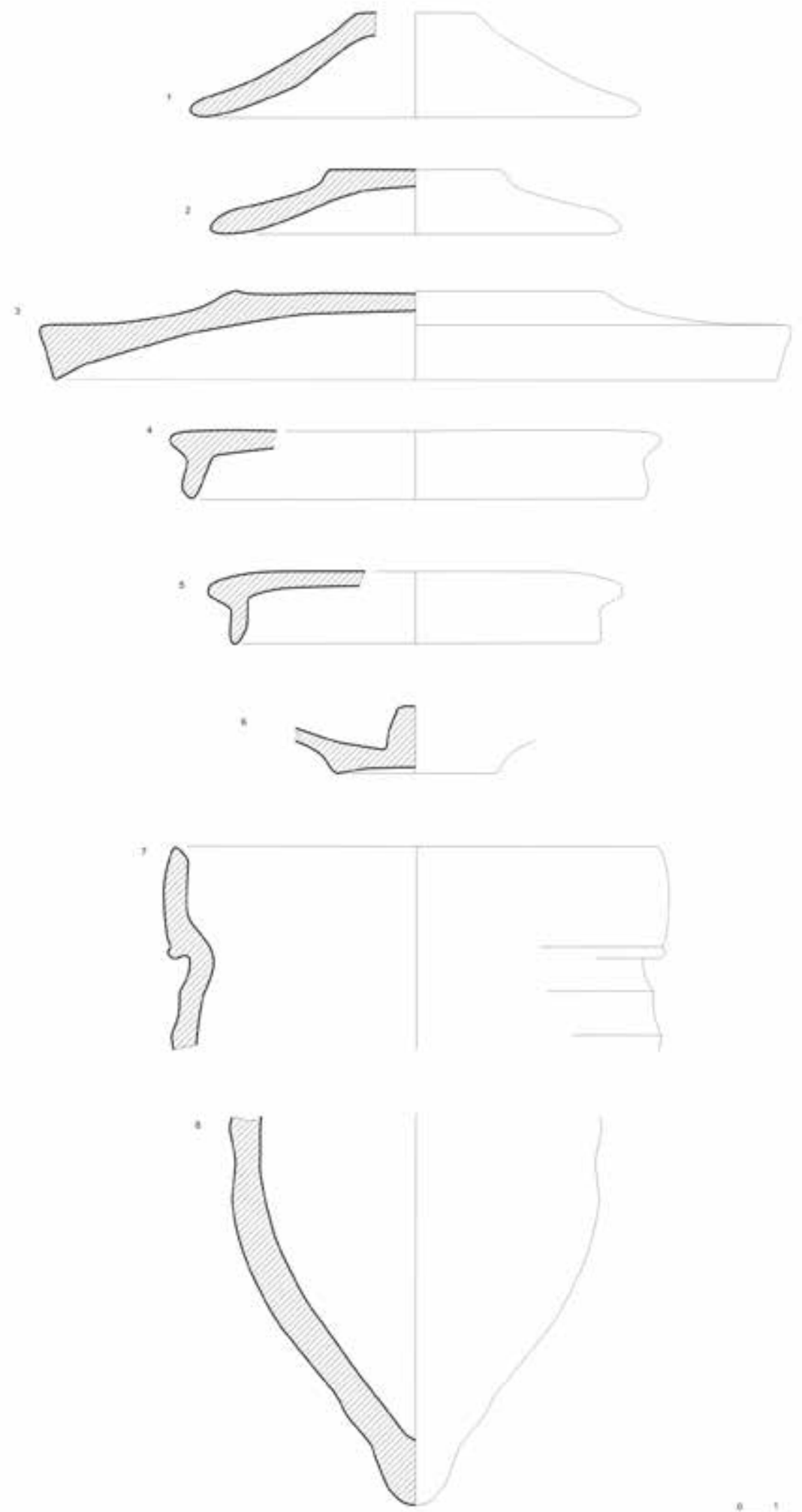

Figura 12. Tapaderas y cangilón. 
(Navarro Palazón, 1986), donde tienen cuellos más esbeltos que los del suroeste de al-Andalus. Además de los paralelos ya indicados en Mértola, en el suroeste se han encontrado ejemplares en Alcácer do Sal (Paixao, Faria y Carvalho, 2001), Albufeira (Gomes, 2002), Silves (Gomes, 1991), Aljezur (Silva y Gomes, 2002), Paderne (Catarino, 1994), Salir (Catarino, 1987), Loulé (Luzia, 2003), Faro (Paulo, 2000), Tavira (Pereira, 2003; Cavaco y Covaneiro, 2010; Diniz, Covaneiro y Cavaco, 2012), Saltés (Bazzana y Cressier, 1989), Cerro Salomón (Pérez Macías, 1999), Castillo de Almonaster la Real (Romero, Rivera y Pérez, 2012), Cortijo del Vico en Aznalcázar (Gonzáles, Pérez y García, 2009), Sevilla (Lafuente Ibáñez, 1997), Carmona (Cardenete et alii, 1992), Setefilla (Kirchner, 1990), y Beca (Cavila Sánchez-Molero, 1992.

\section{VASOS DE USO MÚLTIPLE.}

4.1. Alcadafe (figura 11: 1 a 7 y 10 a 14).

Es una forma muy característica de los ajuares cerámicos andalusíes, y la forma se mantiene sin apenas cambios tipológicos desde época emiral. Nuestros ejemplares responden a la mismo tipo, que corresponde al tipo A de Roselló Bordoy (1978), de base plana, cuerpo tronco-cónico invertido y borde saliente o engrosado al exterior. Las pastas suelen ser castañas o blanquecinas, y por todo tratamiento reciben un fuerte espatulado en la superficie interior.

Sus paralelos son abundantes en todos los contextos geográficos andalusíes, en el suroeste, en el sureste, en la zona levantina, en Baleares, etc., por lo que enumerarlos sin aportar alguna precisión cronológica es una tarea que no tiene el menor sentido.

Uno de los ejemplares tiene una decoración con impresión de cuerda en la parte exterior del borde, decoración que se ha interpretado no como un puro motivo decorativo, sino la impronta de la cuerda que se colocaba para que una forma como ésta, que podía alcanzar grandes diámetros, no se abriera (Salinas Pleguezuelo, 2012). Sin embargo, esto no explica satisfactoriamente por qué unos ejemplares llevan esa impresión y otros no. Algunos investigadores asocian esta decoración de cordaje a la etapa de dominio almohade (Lafuente Ibáñez, 1995).

\section{OBJETOS ADICIONALES.}

\subsection{Tapadera.}

-Tapadera de fondo plano y cuerpo troncocónico (figura 12: 1 y 2). A esta forma parecen corresponder dos ejemplares, aunque no podemos asegu- rar que no estuvieran dotadas de botón central. No es una forma abundante, aunque se ha individualizado en los repertorios cerámicos de los siglos XI a XIII (Bazzana y Bedia, 2005).

-Tapadera de fondo cóncavo, paredes abiertas y borde de sección triangular (figura 12: 3).

Se encuentran paralelos en Córdoba (Salinas Pleguezuelo, 2012), Cádiz (Cavilla Sánchez-Molero, 2005), Sevilla (Huarte Cambra, 2002; Vera y López, 2005), y Mértola (Gómez Martínez, 2004).

-Tapadera con apéndice de botón (figura 12: 6). Según M. Retuerce es un tipo de tapadera muy difundido por toda la geografía de al-Andalus en época almohade (Retuerce Velasco, 1998). Son muy abundantes dentro de los ajuares domésticos en Murcia (Navarro Palazón, 1991). R. Azuar (1989) las fecha en los siglos XI y XII, pero Retuerce (1998) considera que es una forma claramente almohade, de los siglos XII y XIII.

En el suroeste se documentan Santarém (Mendes et alii, 2002), Alcácer do Sal (Carvalho y Faria, 1993), Mértola (Gómez Martínez, 2004), Silves (Gomes, 1989), Castelo Velho de Alcoutim (Catarino, 1987), Saltés (Bazzana y Bedia, 2005), Niebla (Benabat y Pérez, 2003), Barrera y Herrería en Bonares (Pérez Macías, 2002a), Setefilla (Kirchner, 1990), Córdoba (Salinas Pleguezuelo, 2009), Beca (Cavilla Sánchez-Molero, 1992), Jerez de la Frontera (Fernández Gabaldón, 1987; Montes y González, 1987), Mesa de Chiclana (Fernández Barba, 2012), etc.

-Tapadera de fondo convexo y cuello estrangulado formando una incipiente ala (figura 12: 4 y 5). No son muy frecuentes en el suroeste, pero se conocen ejemplares en La Barrera y la Herrería en Bonares (Pérez Macías, 2002a) y Mértola (Gómez Martínez, 2004), donde se fechan en razón del vidriado transparente en los siglos XII y primera mitad del siglo XIII.

\subsection{Arcaduz.}

Entre el lote cerámico del Castillo de Gibraleón también se encuentran un fragmento de arcaduz con el fondo cónico (figura 12: 7 y 8). Aunque es un vaso al que se han asignado también funciones de medida del tiempo, el arcaduz se relaciona directamente en la mayor parte de los casos con la extracción y reparto de agua a partir de norias de pozo y albolafias de río. Una primera tipología fue elaborada del conjunto de los hallazgos del pozo de noria de Oliva (Bazzana, Climent y Montmessin, 

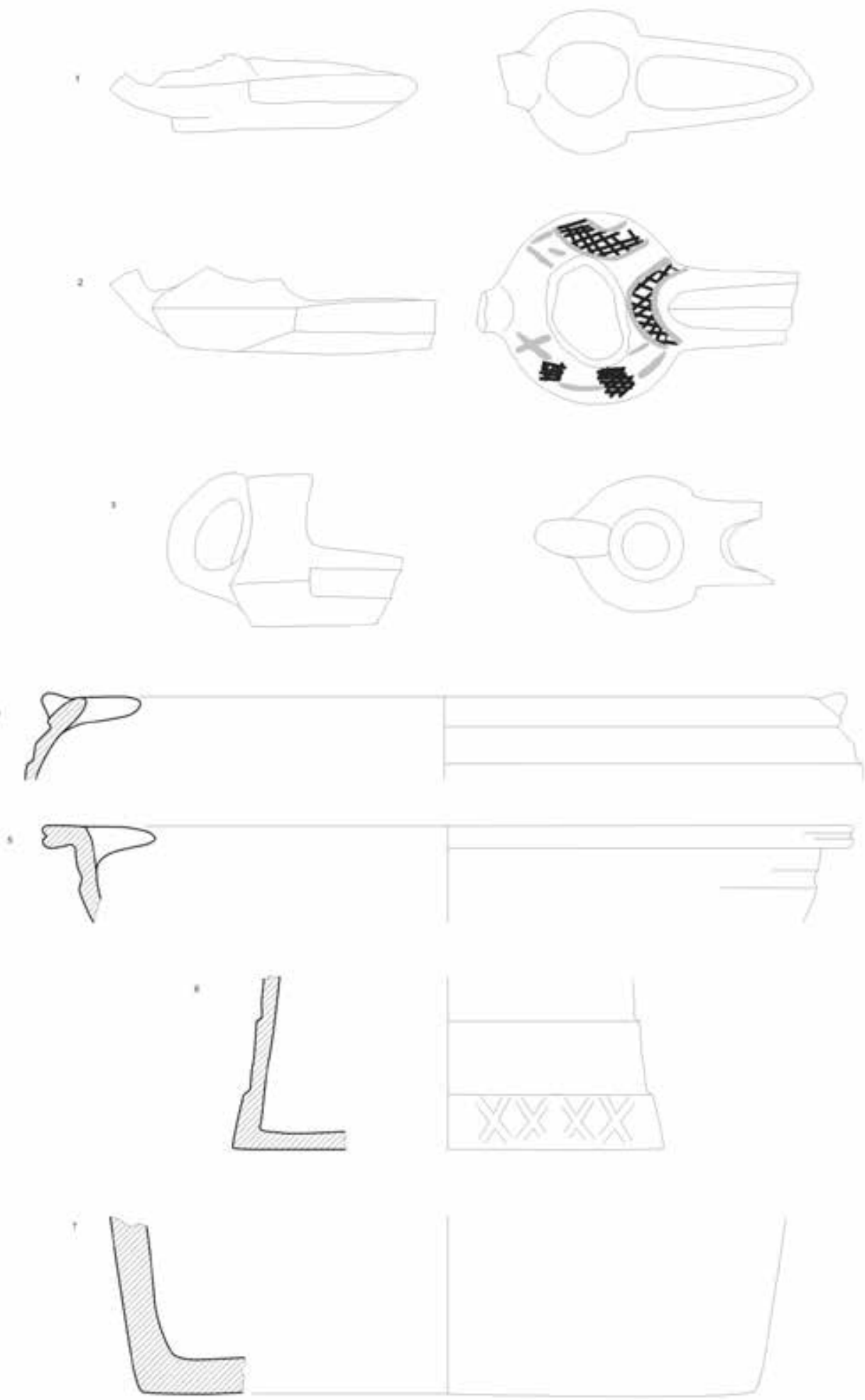

Figura 13. Candiles y anafes. 
1987), y en general pueden establecerse dos grandes grupos, los de fondo cónico y los de fondo plano. Aunque existen múltiples diferencias en la forma de los bordes, tuvieron muy poca evolución a lo largo del tiempo e incluso sus formas perduran después de época medieval.

En la provincia de Huelva destacan los conjuntos del Llano de la Torre en Aroche, de cronología califal-taifa (Pérez Macías, 1989), y los del pozo de noria de La Ollita en Niebla, de época almohade (Benabat y Pérez, 1999). En otros contextos urbanos andalusíes se han encontrado en Sevilla (Carrasco Martín, 1987), Cádiz (Cavilla Sánchez-Molero, 2005) y Murcia (Navarro Palazón, 1986).

\section{CONTENEDORES DE FUEGo.}

\subsection{Candil de pico.}

-Candil de cazoleta carenada y piquera afaceta$\mathrm{da}$ (figura 13: 1 y 3). Corresponde a los tipos $1 \mathrm{E}$ y $1 F$ de Mértola, donde se fechan entre mediados del siglo XI y siglo XII (Gómez Martínez, 2004).

-Candil de depósito lenticular suavemente carenado (figura 13: 2). Está decorado con técnica de cuerda seca parcial. S. Gómez Martínez los data en el siglo XI y sus paralelos más cercanos los señala en Castelo Velho de Alcoutim, Vilamoura, Barrera de Bonares, Saltés, Évora, Moura, y Sevilla (Gómez Martínez, 2004, 432). Algunos ejemplares también han aparecido en Badajoz (Valdés et alii, 2001).

\subsection{Anafe.}

La pieza más interesante fue la publicada al poco de terminar la excavación. Se trata de un "..anafe casi completo de fondo plano y paredes convergentes bitroncocónicas. Pasta rojo anaranjada presentando un engobe superficial naranja claro. Como decoración presenta unas acanaladuras en el galbo enmarcando un estampillado rectangular a dos bandas..." (Bedia García, 1987, 109-110). El estampillado superior es vegetal, estilización de una flor de loto, y el inferior de motivos cordiformes. Así mismo, tiene un abertura de forma polilobulada en la base, rematada en la parte inferior en círculos, para la aireación y la eliminación de cenizas. Debajo de esta abertura aparecen tres incisiones circulares.

En ese momento no se establecieron los paralelos para esta pieza, pero por la decoración estampillada se situó a fines del siglo XII y principios del siglo XIII, en época almohade, momento además al
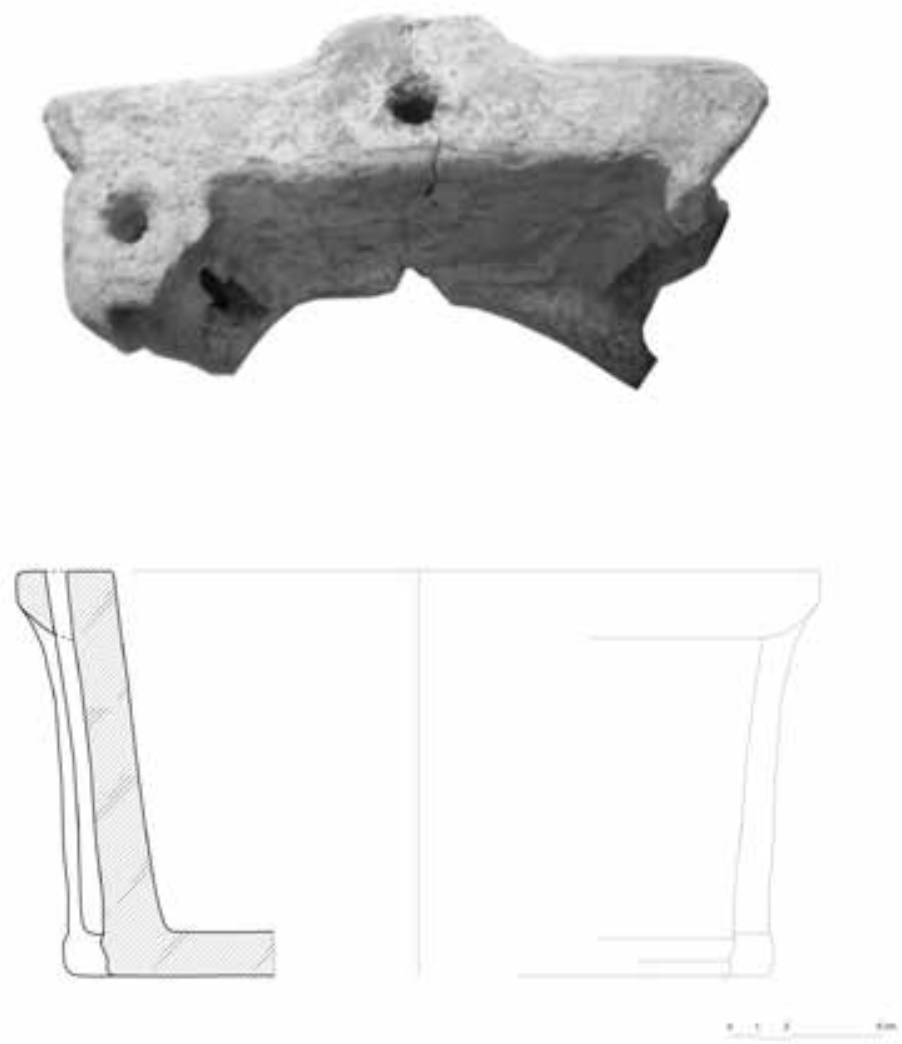

Figura 14. Pila de abluciones. 
que se asignó la mayor parte de las cerámicas inventariadas en la excavación. Este tipo de utensilios domésticos son muy abundantes en el suroeste de alAndalus, en Mértola (Gómez Martínez, 2004), Saltés (Bazzana y Cressier, 1989), Sevilla (Huarte Cambra, 2002), Córdoba (Salinas Pleguezuelo, 2012), Jerez de la Frontera (Fernández Gabaldón, 1987), y Cádiz (Cavilla Sánchez-Molero, 2005). Formas de anafes troncóconicos son también frecuentes en los ambientes almohades de la zona valenciana (Azuar Ruiz, 1989), Murcia (Navarro Palazón, 1991) y La Meseta (Retuerce Velasco, 1998).

Estos hornillos portátiles de sección bitroncocónica se encuentran en todas las comarcas de alAndalus en los mapas de dispersión presentados por Retuerce Velasco (1998, 367), quien plantea que los que tienen la separación por medio de una parrilla son más frecuentes en al-Andalus y es el que caracteriza a los tipos almohades, menos en el área murciana y Almería, donde predominan la separación por barras.

Otro fragmento más incompleto ha podido ser reconocido debido a que parte de su superficie interna esta quemada (figura 15: 6). Se trata de un fragmento de galbo perteneciente a un vaso dividido en dos partes, una inferior, cuyas superficies internas están ennegrecidas por el fuego, y otra superior que no ha tenido contacto con la zona de combustión, forma que coincide con la sección de los anafes. El fragmento llama la atención por la decoración estampillada que lleva al exterior, un friso con metopas de dos motivos repetidos, la mano de Fátima (Khamsa) y motivos entrelazados que recuerdan al cordón de la eternidad. La pasta es depurada, de tonos amarillentos. Aunque no podemos representar su forma completa, es probable que su tipo se acerque a la forma anterior.

Un fondo plano perteneciente a un vaso de forma troncocónica con decoración estampillada (figura 13: 6) también pueden encuadrarse en esta forma, al igual que otros fragmentos de vasos con muñones en la parte interna del borde (figura 13: 4 y 5), pero no tenemos seguridad ya que este tipo de muñones también aparecen en algunos tipos de los vasos trípodes.

\subsection{Pila de abluciones.}

Una serie de vasos en forma de artesa, en general con decoración estampillada y vedrío verde, han sido considerados pequeñas pilas o bandejas de abluciones por su parecido con algunas piezas de piedra a las que se asigna esta función. Es una forma que por su decoración se fecha en época almohade (Pleguezuelo y Lafuente, 1995). El tipo se encuentra bien representado en el suroeste peninsular, en Mértola (Gómez Martínez, 2004), Faro (Paulo, 2000), Silves (Gomes, 1988), Saltés (Bazzana y Cressier, 1989), Niebla (Pavón Maldonado, 1980), y Almonaster la Real (Romero, Rivera y Pérez, 2012).

Con esta serie de recipientes se puede relacionar una de las formas más interesantes exhumadas en la excavación del Castillo de Gibraleón (figura 14). Es un vaso que conserva restos de vidriado verde y un estampillado de tipo geométrico en el borde, con rombos o rectángulos concéntricos. Su perfil es troncocónico y el borde engrosado con el labio plano. Tiene aplicadas ocho costillas verticales en el exterior, cuatro en los ángulos y otras cuatro entre ellos. Estas costillas tienen una perforación vertical en forma polilobulada que arranca del borde. Las perforaciones de los ángulos conectan con el fondo del recipiente en forma de arcos apuntados, mientras las perforaciones que se encuentran en las zona media mueren en el fondo del vaso sin conexión con el fondo interior. Una pieza similar de Saltés se ha considerado una pileta para abluciones y el arco apuntado del fondo interior como la representación de un mihrab (Bazzana y Bedia, 2005, 309). Emparentadas con estas piezas son otros dos ejemplares de pilas de abluciones exagonales, una de Tavira (Pereira, 2003, 20) y otra de Silves (Gomes, 2001, 104). Todos los ejemplares se fechan en época almohade.

\section{CONCLUSIONES.}

Cuando decidimos emprender el estudio de las cerámicas exhumadas en el Castillo de Gibraleón por las excavaciones de Juana Bedia y $\mathrm{M}^{\mathrm{a}} \mathrm{J}$. Carrasco, albergábamos la intención de ir más allá de una simple catalogación tipológica, pretendíamos abrir camino en el conocimiento de esta ciudad islámica del occidente de al-Andalus. El resultado no ha podido ser más satisfactorio, tanto desde el punto de vista de la tipología cerámica, en la que no hemos querido abusar de la presentación de paralelos con otras áreas que no fueran del suroeste peninsular, Garb al-Andalus, como en la posible evolución de la ciudad que pudiera esbozarse del estudio cronotipológico de la cerámica, ya que desgraciadamente no contamos con el diario de la excavación ni con los dibujos originales de planta y secciones de los cortes y estructuras.

Respecto a lo primero cabe destacar que todas las formas que aparecieron asociadas a las estruc- 
turas de la terraza inferior de la fortificación responden a tipos islámicos bastante frecuentes en el oeste peninsular, en el Baixo Alentejo, Algarbe, y las provincias de Huelva, Sevilla, Cádiz, y Córdoba. Hay que resaltar también en este apartado la total ausencia de cerámicas islámicas anteriores a los siglos XII-XIII y bajo-medievales cristianas posteriores a estos siglos. Una vez más se constata la fuerza de la ocupación almohade, un período de grandes obras de fortificación en las ciudades y en el mundo rural, y de refacciones o construcciones de nueva planta en edificios religiosos.
Extraña asimismo que no se reocuparan o aprovecharan las estructuras islámicas y que estas estructuras quedaran selladas por el estrato superficial de abandono, sin que se le superpusieran nuevas construcciones cristianas después de la conquista. Esto quizás pueda explicarse por el uso que recibió en este momento parte de la ciudad islámica después de que la villa de Gibraleón pasara a manos señoriales a comienzos del siglo XIV, en el que la zona excavada quedó de uso exclusivo como alcázar o palacio rodeado de un extenso jardín (figura 2).
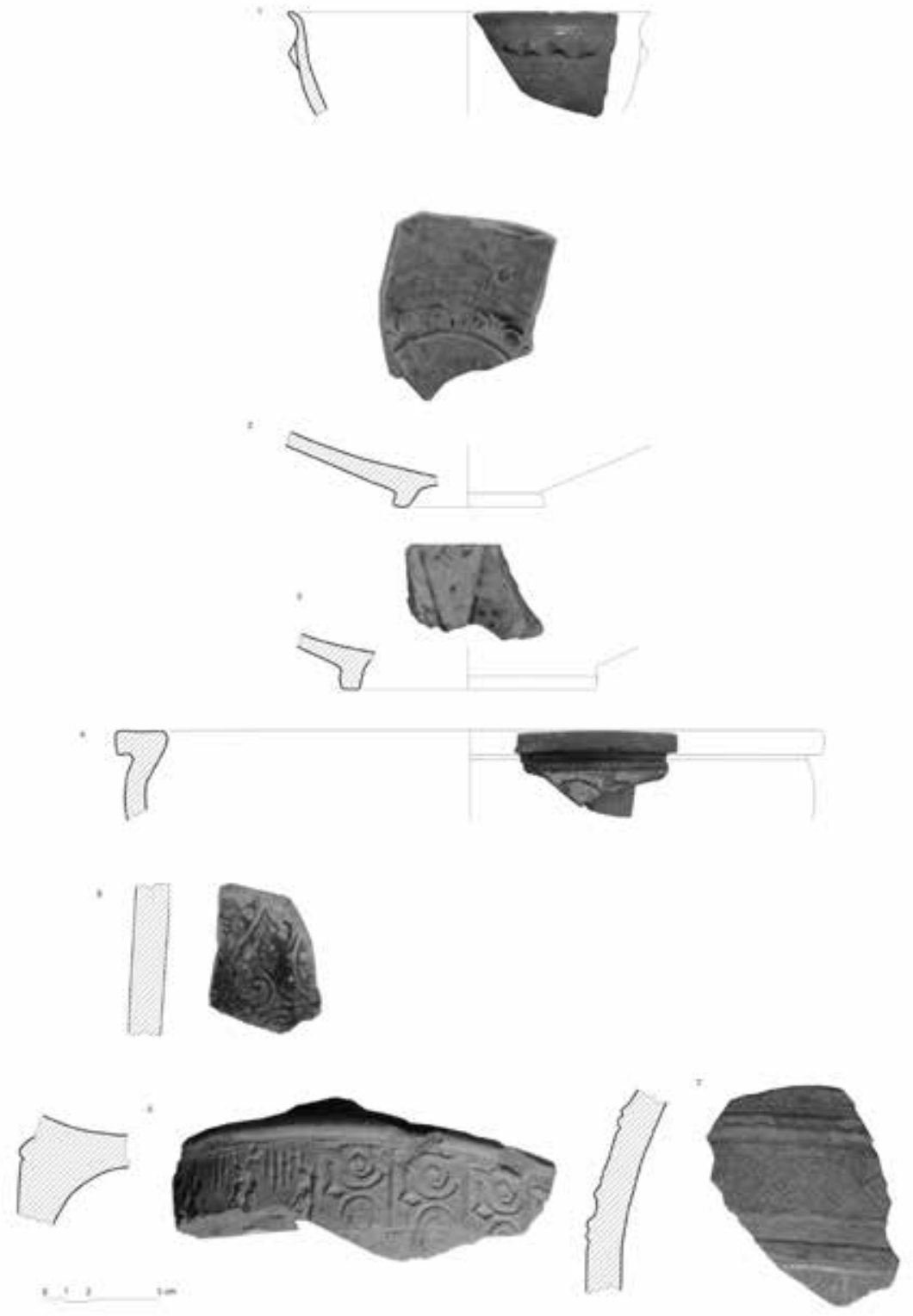

Figura 15. Cerámicas decoradas. 
Para Pavón Maldonado (1996, 42-43) el Castillo de Gibraleón corresponde a una tipología de castillo cuadrangular (cuadriburgium) en la que destaca una Torre Mayor, para el que encuentra paralelos en otros castillos cercanos, como los de Huelva o Moguer, y anota que su cronología islámica estaría avalada por la fábrica de tapial. Según su opinión su origen se remontaría el siglo $\mathrm{X}$, pues tanto Ibn Hayyan como al-Idrisi catalogan a Gibraleón como lugar fortificado. Este castillo islámico tendría una extensión de unos 5.400 metros cuadrados y se complementaría con un albácar en el mismo cabezo, al que corresponden los restos de una cerca de tapial con una torre con esquinales de sillares encadenados, similares a las torres de las murallas de Niebla y del castillo de Aroche.

No consideró la posibilidad de que las fábricas de tapial se hayan prolongado en el tiempo, hasta época bajomedieval, y esto no le lleva a diferenciar las distintas fábricas de tapial. Parece demostrada la continuidad de la construcción en tapial en los castillos de la campiña onubense en época bajomedieval, por citar los de Palos, Moguer y Cartaya, cuya fecha de construcción está recogida en las fuentes y en los que se han realizado excavaciones y estudios de los materiales cerámicos que se encuentran en el tapial (Pozo, Campos y Borja, 1996; Carriazo y Cuenca, 2004). La torre de San Bartolomé de la Torre es también un claro ejemplo de la perduración de este tipo de fábrica en las fortificaciones cristianas (Bedia y Teba, 1987), y su empleo puede estar motivado por la inexistencia de materiales pétreos en la campiña. La torre de mayor formato responde igualmente a los nuevos modelos de castillos bajomedievales cristianos, denominadas en las fuentes como Torre Mayor o Torre del Homenaje, según se recoge también en el caso del castillo de Gibraleón.

Amén del escaso aparato bibliográfico que acompaña a su estudio, su planteamiento adolece en definitiva de un grave problema, su total desconocimiento del proceso histórico que afectó a este edificio y de las modificaciones que ha sufrido a lo largo del tiempo Por tanto, en su descripción malinterpreta los restos datándolos en un mismo período, y no llega distinguir en el castillo la cerca de época islámica, con torres con esquinales de sillarejo encadenado, que confunde con un albácar del castillo, y el alcázar construido en época bajomedieval cristiana.

En primer lugar, su cuadriburgium califal aparece claramente diferenciado en la planta del siglo XVII como Palacio de los Duques de Béjar (Duclos
Bautista, 2002; Carriazo y Cuenca, 2004, 191). Por todo esto, nos parece que la planta del castillo que Pavón Maldonado sitúa en el siglo X no son más que los restos del Palacio de los Duques de Béjar, que se construyó en el antiguo alcázar cristiano. Este alcázar, de fábrica de tapial y con Torre $\mathrm{Ma}$ yor, aparece citado desde la etapa de señorío de los herederos de Alfonso de la Cerda. En segundo lugar, los restos de cerca de tapial con torre con esquinales de sillarejo encadenado que rodean a este alcázar/palacio no es un albácar del castillo, pues es imposible que fuera recinto para el ganado, ya que las excavaciones de Juana Bedia y María Jesús Carrasco han demostrado que en esa zona, utilizada como jardín en el Palacio de los Duques de Béjar, existe una trama urbana de época almohade.

Esta cerca de tapial de cronología islámica que rodea al Palacio de los Duques de Béjar quizás pueda relacionarse con la antigua alcazaba islámica, convertida en alcázar/castillo después de la conquista, pues la existencia de una zona residencial dentro de la alcazaba es corriente en otros asentamientos islámicos cercanos, como en la alcazaba de Mértola (Macías, 1996). Esta cerca islámica del castillo de Gibraleón hay que diferenciarla pues de la cerca o muro que rodearía la población, que como hemos recogido se cita también después de la conquista, pero de la que no conservamos ningún elemento.

Aunque está bien definida la muralla de la ciudad en época bajo-medieval (Mira Toscano, 2012), resulta complicado proponer el trazado del núcleo de la ciudad islámica en el actual callejero de Gibraleón. No obstante, aunque erremos en nuestra propuesta, no queremos dejar pasar la ocasión de apuntar algunas reflexiones que ayuden a iniciar la discusión de este tema. Pensamos que el perímetro de la madina se encuentran en los alrededores de la parcela del Castillo de Gibraleón, en el Barrio del Otero (figura 16), de manera clara en sus lados norte, este y oeste por las calles Avda. de los Reyes Católicos, Calle Palacios, Calle de la Fuente, y Plaza de Santiago, mientras en el lado sur deberíamos colocar su límite en el conocido como Callejón de la Azuda, al exterior de lo que debería ser el principal eje de la ciudad, la Calle Ríos, que corresponde al recorrido del antiguo camino procedente de Sevilla (figura 16). Dentro de esta manzana se encuentran otras calles, como la Calle Villadentro, que se adosa a la parcela del castillo, y la calle Hinojosa, que se encuentra entre la Calle Villadentro y la Calle Ríos. Todas estas calles son perpendiculares al rio y pa- 

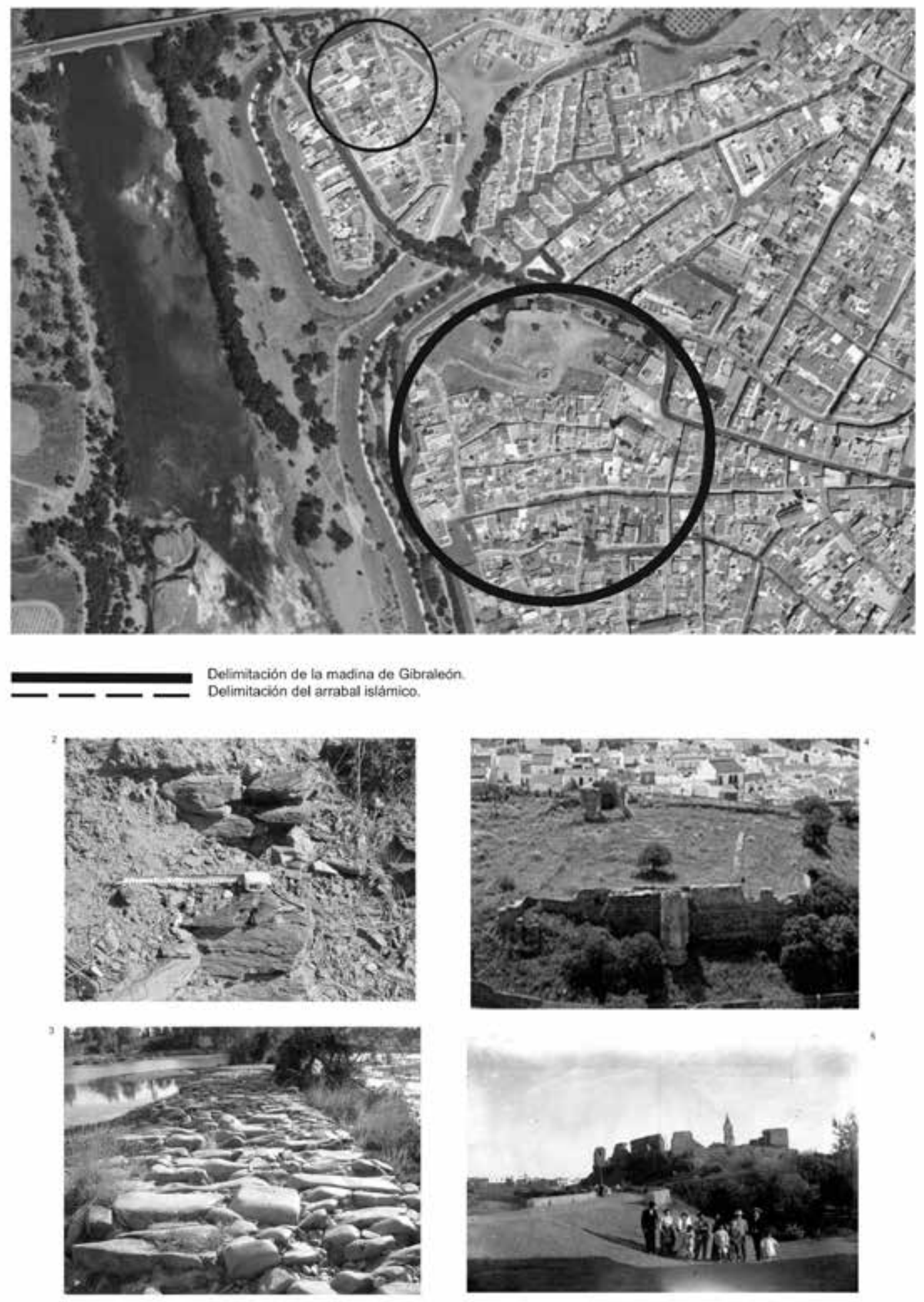

Figura 16. Gibraleón: 1, propuesta de situación de la madina y el arrabal; 2, estructuras del arrabal islámico junto al Arroyo de la Bocina; 3, badén de la Zua; 4, Castillo de Gibraleón, en primer término cerca islámica de tapial y torre con sillarejo encadenado en las esquinas, y en segundo término el Palacio de los Duques de Béjar adosado a ella; y 5 , foto antigua con los restos del Palacio de los Duques de Béjar al fondo. 
ralelas a la Calle Ríos, mientras que fuera de este sector comienzan calles con una orientación diferente, perpendiculares a la Calle Ríos y paralelas a la corriente del río, una traza urbanística claramente distinta que debió iniciarse con las ampliaciones de época bajo medieval.

Dentro de la ciudad sólo podemos proponer por ahora que el Castillo de Gibraleón puede identificarse con la antigua alcazaba islámica, que se mantendría en época bajomedieval como alcázar señorial, hasta su transformación definitiva en Palacio de los Duques de Béjar en 1568, cuando Francisco III Diego de Zuñiga y Sotomayor decide instalar la corte señorial en Gibraleón (Mira Toscano, 2012). En este barrio se encontraba la iglesia de San Juan Bautista, pero habida cuenta de que las antiguas mezquitas se cristianizaron y consagraron siempre a nombre de la virgen María, no está claro que ella fuera la mezquita.

Con esta delimitación tendríamos que la ciudad islámica de Gibraleón pudo contar con una superficie de unas 3,57 hectáreas. Si comparamos esta superficie con las medidas de otras ciudades próximas cuyo perímetro podemos conocer gracias a la conservación íntegra de sus cercas urbanas, caso de Niebla (18 hectáreas) y Tejada la Nueva (3,97 hectáreas), sería comparable con Tejada la Nueva, que fue capital del distrito sevillano de al-Basal.

Pero, como en el caso de Niebla (Campos, Gómez y Pérez, 2007), Gibraleón contó además con un arrabal extramuros, que se situaba al otro lado del Arroyo de la Bocina, en los alrededores de la Calle Juan XXIII, donde en algunos taludes hemos detectado restos de estructuras de habitación en conexión estratigráfica con cerámicas islámicas (figura 16). Es posible que este arrabal ocupara todo el cerro que se extiende entre el Arroyo de la Bocina y la actual carretera general hacia Ayamonte, pero no corresponde al arrabal que se cita en la documentación bajo-medieval (Mira Toscano, 2012).

\section{Bibliografía.}

Alarcón, F.J. Cavila, F. y Aguilera, L. (1993), Intervención Arqueológica de Emergencia la Bovedilla (Benaocaz), Anuario Arqueológico de Andalucia/1991, III, 37-42.

Alba, M. y Feijoo, S. (2003), "Pautas evolutivas de la cerámica común de Mérida en épocas visigoda y emiral", Anejos de Archivo Español de Arqueología, XXVIII, 483-504.

Álvaro Sánchez, R. (2000), "Cerámica almohade de
Cacela Velha: primeros avances", $3^{\circ}$ Congreso de Arqueología Peninsular, VII, Vila Real, 453-464.

Amador de los Ríos, R. (1891), Huelva, Barcelona (Reimp. Huelva, 1983).

Anasagasti, A. M M $^{\mathfrak{a}}$ y Rodríguez, L. (1984), Niebla en la época de Alfonso $X$, Huelva.

Asín Palacios, M. (1944), Contribución a la toponimia árabe de España, Madrid-Granada, II Edición.

Azuar Ruiz, R. (1989), Denia islámica. Arqueología y poblamiento, Alicante.

Bazzana, A. y Bedia, J.-Dirs.-, 2005, Excavaciones en la isla de Saltés (Huelva) 1988-2001, Sevilla.

Bazzana, A., Climent, S. y Montmessin, Y. (1987), El yacimiento medieval de les Jovades-Oliva (Valencia), Valencia.

Bazzana, A. y Cressier, P. (1989), Shaltísh/Saltés (Huelva). Une ville médiévale d'Al-Andalus, Madrid.

Bazzana, B. y N. Trauth, N. (1997), "L'Île de Saltés (Huelva): une ville islamique, centre d'une métallurgie de concentration au Moyen Âge”, Académie des Inscriptions et Belles-Lettres, Comptes Rendus de seances de l'anné 1997, 47-74.

Bedia, J. y Carrasco, Mª J. (1987a), "Informe arqueológico: excavaciones de urgencia en el castillo de Gibraleón (Huelva)", Anuario Arqueológico de Andalucía / 1986, III, 182-187.

(1987b), "Avance de los trabajos realizados en el Castillo de Gibraleón (Huelva)”, II Congreso de Arqueología Medieval Española, II, Madrid, 103-112.

Bedía, J., Teba, J.A. y Pérez, J.A. (1985), Inventario de yacimientos arqueológicos de la provincia de Huelva para la Prevención de Urgencias, Delegación Provincial de Cultura de la Junta de Andalucía en Huelva, Inédito.

Bedia, J. y Teba, J.A. (1987), "Informe arqueológico: un corte estratigráfico en la torre de San Bartolomé (Huelva)", Anuario Arqueológico de Andalucía/1986, III, 155-160.

Belén, Ma y Escacena, J.L. (1992), "Niebla (Huelva). Excavaciones junto a la Puerta de Sevilla (1978-1982). La cata 8”, Huelva Arqueológica, XII, 167-306.

Beltrán Pinzón, J.M. (2007), "Registros cerámicos de época Taifa en madina Labla (Niebla, Huelva): un acercamiento tipológico", Huelva en su 
Historia, 12, 53-76.

Benabat, Y. y Pérez, J.A. (1999), "La Ollita, una noria islámica en Niebla", Huelva en su Historia, 7, 233-243.

(2003), "Apunte sobre el ajuar cerámico del siglo XII en Niebla”, Arqueología Medieval, 8, 119128.

Bendala Galán, M. (1987), "Ab ostio fluminis Anae ...”, Cuadernos de Prehistoria y Arqueología de la Universidad Autónoma de Madrid, 11/12, 129-139.

Campos, J.M., Pérez, J.A., Gómez, F., y Benabat, Y. (2000), "Arqueología urbana en Niebla. El solar de la calle Cristóbal Colón-10", Anuario Arqueológico de Andalucía/1995, III, 228236.

Campos, J.M. Gómez, F. y Pérez, J.A., (2007), Ilipla/Niebla. Evolución urbana y ocupación del territorio, Huelva.

Cardenete, R., Gómez, M.T., Jiménez, A., Lineros, R. y Rodríguez, I. (1992), "Excavaciones arqueológicas de urgencia en el solar de la plazuela de Lasso s/n, Carmona, Sevilla", Anuario Arqueológico de Andalucía / 1990, III, 503-509.

Carrasco Martín, Mª J. (1987), “Avance al estudio de las cerámica hispano-musulmana procedente de los Baños de la Reina Mora (Sevilla)", II Congreso de Arqueología Medieval Españo$l a, I V$, Madrid, 529-538.

Carriazo, J.L. y Cuenca, J. Mª , (2004), Huelva, Tierra de Castillos, Huelva.

Carvalho, A.R. y Faria, J.C. (1994), "Cerâmicas muçulmanas do Museu Municipal de Alcácer do Sal", Arqueología Medieval, 3, 101-112.

Catarino, H. (1992), Cerâmicas Islâmicas do Castelo de Salir, Loulé.

Cavaco, S. y Covaneiro, J. (2010), "Materiais cerâmicos proivenientes de um silo de Barrio Almóada do convento de Graça-Tavira”, Arqueología Medieval, 11, 103-112.

Cavilla Sánchez-Molero, F. (1990), "La cerámica islámica de Barbesula (San Roque, Cádiz). Apuntes sobre las producciones almohades del suroeste peninsular”, Anuario Arqueológico de Andalucía / 1988, III, 64-70.

(1992), La cerámica hispano-musulmana de Beca (Caños de Meca, Cádiz), Cádiz.

(1993), "Jarros con pitorro de época almohade", Estudios de Historia y Arqueología Medievales, IX, 106-121.

(2005), La cerámica almohade de la Isla de Cá- diz (Ŷ̀az̄rat Qādis), Cádiz.

Choclán, C. y Castillo, J.C. (1991), "Excavación de urgencia en el solar c/ San Francisco, 3, y c/ Juan Robledo, 12, de Andújar”, Anuario Arqueológico de Andalucía/1989, III, 319-327.

Correia, F.B. (1991), "Um conjunto cerâmico arabemedieval de Beja”, A Cerâmica medieval no Mediterráneo Ocidental, Mértola, 373-385.

Cressier, P., Riera, Mª M., y Roselló, G. (1991), "La cerámica tardo almohade y los orígenes de la cerámica nasrí”, A cerâmica medieval no Mediterrâneo Ocidental, Mértola , 215-246.

Diniz, T., Covaneiro, J. y Cavaco, S. (2012), "Formas de cerâmica almóada provenientes do Convento de Graça (Tavira)", Arqueología Medieval, 12, 169-177.

Duclos Bautista, G. (2002), La fortificación de un territorio. Arquitectura militar en la raya de Huelva, siglos XVII y XVIII, Huelva.

Estorninho, A. Martins, A., Ramos, C., y J. Muralla, J. (1994), "O povoamento da área de Aljustrel. Seu encuadramento na Faixa Piritosa Alentejana”, Arqueología en el entorno del Bajo Guadiana, Sevilla, 27-36.

Fernández Barba, R. (2012), Aporte de la Mesa (Chiclana de la Frontera, Cádiz) al estudio de la cerámica islámica de Garb al-Andalus, Cádiz.

Fernández Gabaldón, S., (1987), "El yacimiento de la Encarnación (Jerez de la Frontera): bases para la sistematización de la cerámica almohade en el S.O. peninsular", al-Qantara, VIII, 449-474.

(1992), "Primeros datos arqueológicos acerca del Aroche hispanomusulmán (Aroche, Huelva). Estudio de los materiales recogidos en superficie”, Huelva Arqueológica, XII, 307-378.

Ferreira, I.C. (2004), O Castelo de Palmela do islâmico ao cristão, Lisboa.

Fuertes Santos, $M^{a}$ C. (2002), La cerámica califal del yacimiento de Cercadilla, Sevilla.

García Sanjuán, A. (2003), Evolución histórica y poblamiento del territorio onubense durante la época andalusí (siglos VIII-XIII), Huelva.

Giles, F. y Mata, E. (2001), "Intervención Arqueológica en calle de Santo Domingo, no 9, El Puerto de Santa María, Cádiz”, Anuario Arqueológico de Andalucía / 1998, III-1, 58-65.

Gomes, R. V.(1988), Cerâmicas musulmanas Do Castelo de Silves, Xelb, 1, Silves.

(2001), Palácio almóada da Alcáçova de Silves,Lisboa. 
Gómez Martínez, S. (2002), A cerâmica em corda seca de Mértola, Mértola.

(2004), La cerámica islámica de Mértola: producción y comercio, Madrid.

Gómez, S. y Lópes, V. (2012), "Cerámicas del arrabal de Mértola (Portugal). Contexto y uso de los objetos en un espacio ribereño andalusí”, Atti del IX Congresso Internazionale sulla Ceramica Medievale nel Mediterraneo, Firenze, 566-568.

Gonçalves, C. y Silva, T. (2009), "O período islámico em Faro. Resultados preliminares”, Xelb, 9, 563-570.

González, J., (1951), Repartimiento de Sevilla, Sevilla.

González, D., Pérez, J.A. y García, P. (2009), “Cerámicas de la alquería de Cortijo del Vico (Aznalcázar, Sevilla)", IV Encuentro de Arqueología del Suroeste Peninsular, Huelva, 1336-1357.

Hernández Giménez, F. (1958), "El cruce del Odiel por la vía romana de Ayamonte a Mérida”, Archivo Español de Arqueología, XXXI, 126152.

Huarte Cambra, R. (2002), "Intervención Arqueológica en el Real Alcázar de Sevilla: análisis tipológico-estratigráfico de los materiales cerámicos”, Anuario Arqueológico de Andalucía/1999, II, 234-247.

Hunt Ortiz, M.A. (1999), "Intervención arqueológica de urgencia en el yacimiento Cerro del Castillo, Aznalcóllar (Sevilla)", Anuario Arqueológico de Andalucía/1995, III, 507-512.

Jiménez, C., Cavilla, F., Aguilera, L. y Richarte, M ${ }^{\mathrm{a}}$ J. (2001), "Intervención de urgencia en el yacimiento de Iptuci, Cabezo de Hortales (Prado del Rey, Cádiz). Proyecto ruta histórico-cultural, $2^{\mathrm{a}}$ campaña 1994-1995”, Anuario Arqueológico de Andalucía / 1996, 37-44.

Juárez Martín, J.M. (1999), “Intervención Arqueológica en el recinto del antiguo cementerio de Estepa”, Anuario Arqueológico de Andalucía/1995, III, 539-545.

khawli, A. (1993), "Introdução o estudo das vasilhas de armazenamiento de Mértola islámica”, Arqueología Medieval, 3, 63-78.

Kirchner, H., (1990), Etude des céramiques islamiques de Shadhfilah (Setefilla, Lora del Rio, Séville), Lyon.

Ladero Quesada, M.A. (1977), "Los señores de Gibraleón", Cuadernos de Historia, 7, 33-95.

Lafuente Ibáñez, P. (1997), "La cerámica medie- val”, El Real Monasterio de San Clemente. Una propuesta arqueológica, Sevilla, 107-129.

Luzia, I. (2003), “Testemunhos da Ocupação Islâmica em Al-Ulya. Estructuras e Cerâmicas”, Xelb, 4, 219-234.

Macías, S. (1992), "Silos 4 e 5 de Mértola. Uma proposta de datação do espólio cerâmico", Arqueología Medieval, 1, 27-33.

(1993), "Moura na baixa idade média: elementos para um estudo histórico e arqueológico”, $A r$ queología Medieval, 2, 127-157.

(1996), Mértola Islâmica. Estudo histórico-arqueológico do Bairro da Alcaçoba (séculos XII-XIII), Mértola.

Madoz, P. (1847), Diccionario Geográfico-Estadístico-Histórico de España y sus posesiones de Ultramar, IX, Huelva, Reimpresión Huelva (1988).

Mateu y Llopis, F. (1952), "Hallazgos numismáticos, VI”, Al-Andalus, XVII-1, 442-444.

Mendes, H., Pimienta, J. y Valongo, A. (2002), "Cerâmicas medievais provenientes da excavação da lameira $\mathrm{n}^{\mathrm{0}} 21$. Centro Histórico de Santarém”, Revista Portuguesa de Arqueología, 5/1, 259-270.

Mira Toscano, A. (2012), El Convento de la Madre de Dios del Vado: una fundación señorial de la Casa de Béjar en Gibraleón, Trabajo Fin de Máster, Dpto. de Historia II. Universidad de Huelva.

Molina Carrión, M. (1993), "Informe de la excavación de urgencia en la iglesia de las Monjas Concepcionistas (Vejer de la Frontera, Cádiz)”, Anuario Arqueológico de Andalucía/1991, III-1, 94-103.

Montes, C. y González, R. (1987), “Excavaciones arqueológicas de urgencia en el casco urbano de Jerez de la Frontera (C/ Barranco 10)", Anuario Arqueológico de Andalucía / 1986, III, 75-81.

Mazzoli-Guintard, C. (2000), Ciudades de al-Andalus. España y Portugal en la época musulmana (s. VIII-XV), Granada.

Navarro Palazón J. (1986), La cerámica islámica de Murcia, Murcia.

(1991), Una casa islámica en Murcia Estudio de su ajuar (siglo XIII), Murcia.

Paixão, A.C. y Carvalho, A.R. (2001), "Cerámicas almohades de al-Qasr al-Fath (Alcácer do Sal)”, Sítios islámicos do Sul Peninsular, LisboaMérida, 199-230.

Pardo Rodríguez, Mª L. (1980), Huelva y Gibra- 
león (1282-1485): documentos para su historia, Huelva.

Pavón Maldonado, B. (1980), "Miscelánea de arte y arqueología hispanomusulmana, I. Notas sobre cerámica islámica de Niebla", al-Qantara, 1, 405-410.

(1990), Tratado de Arquitectura Hispanomusulmana, I. El Agua, Madrid.

(1996), Arquitectura islámica y mudéjar en Huelva y su provincia. Prototipos y espacios en la Andalucía occidental, Huelva.

Pereira, R.M. (2003), A gramática decorativa da talha almóada de Tavira, www.arkeotavira. com/Estudos/Talha.

Pérez Macías, J.A. (1989), "Prospección arqueológica superficial del yacimiento hispanomusulmán de El Ladrillero de Aroche (Huelva)", Anuario Arqueológico de Andalucía/1987, III, 323329.

(1999), "Cerro Salomón y la minería hispanomusulmana en Garb Al-Andalus”, Arqueología Medieval, 6, 19-38.

(2002a), El poblamiento andalusí en la campiña de Bonares, Huelva.

(2002b), "El asentamiento rural andalusí en Vallelejo (Rociana del Condado, Huelva)", Anales de Prehistoria y Arqueología, 17-18, 509-522.

(2002c), "La herrería califal-taifa del Cabezo de la Mina (Lucena del Puerto, Huelva)", Spal, 11, 419-432.

(2006), "Renegados, rebeldes y protegidos. Arqueología y poblamiento muladí en el suroeste de al-Andalus", Espiritualidad y convivencia en al-Andalus (F. Roldán Castro, Ed.), Huelva, 91-126.

(2012), "Pie Castillo y la fortificación del Camino de la Raya", Fortificaciones, Guerra y Frontera en el Marquesado de Gibraleón (J.L. Carriazo Rubio, Ed.), Huelva, 15-44.

(2011), "La alquería de Marchar Palmet (Alcalá de la Alameda, Chucena, Huelva)", Tudmir, 2, 141150.

Pérez, J.A. y Bedia, J. (1993), “Un lote de cerámica islámica de Niebla”, Arqueología Medieval, 2, 55-62.

Pérez, J. A. y Serrano, L., (2004), "La alquería de Purchena (Chucena, Huelva)”, Arqueología y Territorio Medieval, 11-1, 7-22.

Pérez, J.A., Ovejero, G. y Schattner, Th. G., (2008), "Explotación medieval de hierro en la comarca de El Pedroso (Sierra Norte, Sevilla)", Estudios de Minería Medieval en Andalucía (J. A. Pérez y J. L. Carriazo, Eds.), Huelva 23-26.

Pleguezuelo, A. y Lafuente, Mª P., (1995), “Cerámicas de Andalucía Occidental (1200-1600)", Spanish Medieval Ceramics in Spain and the British Isles, BAR Internacional Series, 217-244.

Pozo, F., Campos, J.M. y Borja, F. (1996), Puerto Histórico y Castillo en Palos de la Frontera (Huelva): asentamiento humano y medio natural, Huelva.

Ramírez del Río, J. (2012), "Al-Dajīra al-Saniya: una fuente relevante para el siglo XIII en la Península Ibérica”, al-Qantara, XXXIII-1, 7-44.

Rego, M. (2003), "A ocupação Islâmica de Noudar”, Arqueologia Medieval, 8, 69-82.

Retuerce Velasco, M. (1998), La cerámica andalusí de la Meseta, Madrid.

Rodríguez Martinho, J. (1972),”Ainda sobre um achado de quirates em Gibraleón, Huelva (Espanha)", O Arqueólogo Portugués, VIII-6, 281-288.

Roldán Castro, F. (1993), Niebla musulmana (siglos VIII-XIII), Huelva.

(2005):" Textos árabes haciendo referencia a Saltés", Excavaciones en la isla de Saltés (Huelva) 1988-2001 (Bazzana, A. y Bedia, Dirs.), Sevilla, 379- 384.

Romero, E., Rivera, T. y Pérez, J.A. (2012), “Cerámicas islámicas de Almonaster la Real y Aracena”, Arqueología medieval, 12, 129-154.

Roselló Bordoy, (1978), Ensayo de sistematización de la cerámica árabe de Mallorca, Palma de Mallorca.

(1988), "Algunas puntualizaciones sobre el ataifor andalusí: tipología y cronología", Homenaje a Gratiniano Nieto, II. Cuadernos de Prehistoria y Arqueología de la Universidad Autónoma de Madrid, 13-14, 281-289.

Ruiz, J.A. y López, J.J. (2001), “Excavación en Pocito Chico (El Puerto de Santa María). Campaña de 1998", Anuario Arqueológico de Andalucía / 1998, III-1, 79-92.

Salinas Pleguezuelo, $M^{\mathrm{a}}$ E. (2008), "Un vertedero urbano de época tardoalmohade en Córdoba”, La cerámica en entornos urbanos y rurales en el Mediterráneo medieval (A. García y F. Villada, Eds.), Ceuta, 315-355.

(2009), "La cerámica tardoalmohade en Córdoba y su relación con el suroeste peninsular", IV Encuentro de Arqueología del suroeste peninsu- 
lar, Huelva, 1316-1335.

(2012), La cerámica islámica de madinat Qurtuba de 1031 a 1236: cronotipología y centros de producción, Córdoba.

Sánchez, J.Ma (1999), Huelva y su provincia en las Relaciones Geográficas de Don Tomás López, Sevilla.

Serrano, L., Campos, P. y Pérez, J.A. (e.p.), “A propósito de dos nuevas localizaciones de época prerromana en la desembocadura del río Odiel (Huelva): Las Monizas II y Gibraleón”, VII Encuentro de Arqueología del Suroeste, Aroche (2013).

Silva, C.T. y Gomes, R.V. (2002), "Primeros resultados das escavações arqueológicas no Castelo de Aljezur”, Mil anos de Fortificações na Península Ibérica e no Magreb (500-1500), Palmela, 347-356.

Teichner, F. (1994), "Évora. Vorbericht über die Ausgrabungen am Römischen Tempel (19861992)", Madrider Mitteilungen, 35, 336-358.

(1998), "Spuren islamischer Besiedlung auf dem Castillo de Mulva (Villanueva del Río y Minas, Prov. Sevilla)?", Madrider Mitteilungen, 39, 323-335.

Torres, C., Palma, M.P., Rego, M. y Macías, S. (1991), "Cerâmica Islâmica de Mértola. Proposta de cronología e funcionalidade”, A Cerâmica Medieval no Mediterrâneo Ocidental, Lisboa, 497-536.

Valdés Fernández, F. (1985), La alcazaba de Badajoz (1977-1982) y testar de la Puerta del Pilar, Excavaciones Arqueológicas en España, 144, Madrid.

Valdés, F., Cortés, D., Díez del Diego, S., Durán, F.J., y Sordo, E. (2001), "La cerámica andalusí de la ciudad de Badajoz. Primer período (siglos IX-XII), según los trabajos en el antiguo Hospital Militar y en el área del aparcamiento de la c/de Montesinos”, Garb, Sitios islámicos del Sur Peninsular, Lisboa-Mérida, 199-230.

Valencia Rodríguez, R. (1996), "Lepe árabe (siglos VIII-XIII)", Historia de Lepe. Una proyección hacia el futuro (Juana Otero Prieto, Dir.), Huelva, 83-102.

Valor Piechotta, M. (1982), “Aún más sobre Cuatrovita: análisis de sus fuentes documentales y prospección arqueológica”, Estudios de Historia y de Arqueología Medievales, II, 127-135.

Vera, M. y López, P. (2005), La cerámica medieval sevillana (siglos XII al XIV): la pro- ducción de Triana, BAR International Series, 1403, Oxford.

Vidal, N., Campos, J.M., Gómez, A., y Sánchez, L. J. (2008), "Arqueología rural islámica en Huelva. La alquería de La Almagra”, Arqueología Medieval, 10, 65-104. 
